\title{
LAS DIFERENCIAS ENTRE LA JURISPRUDENCIA ANDALUSÍ Y EL RESTO DE LA ESCUELA DE MĀLIK: EL TEXTO ATRIBUIDO A ABŪ ISHĀQ AL-GARNĀṬI
}

\author{
Alfonso CARMona GonZÁlez
}

Universidad de Murcia

En los libros andalusíes de jurisprudencia aparecen con cierta frecuencia expresiones como al-'amal 'inda-nã bi-l-Andalus «la práctica vigente entre nosotros en al-Andalus». La palabra 'amal (usus fori, práctica judicial) no necesariamente hay que entenderla en el sentido de que existieran aquí unos usos legales que podamos calificar de exclusivamente andalusíes. Generalmente, con esa palabra sólo se indica que, ante dos soluciones diferentes propuestas dentro de la escuela mālikī, los tribunales andalusíes se inclinaban habitualmente por una de ellas ${ }^{1}$. Es decir, la «singularidad jurídica» que algunos han creído ver en nuestros alfaquíes fue muy relativa, y la tradición de Córdoba no introdujo cambios significativos en el corpus de doctrina mãlikī, a pesar de que López Ortiz haya llegado a decir que los alfaquíes «españoles» imprimían a la jurisprudencia mālikĩ una tendencia propiamente «nacional». Aserto que él basa en la afirmación de Ibn Jaldūn de que no se podía considerar a un jurista competentemente formado en la escuela de Mālik mientras no fuera capaz de distinguir los matices que separaban, dentro de esa corriente, las «facciones» andalusí, iraquí e ifriquí ${ }^{2}$.

Pero, como digo, tales «matices» solían permanecer dentro de la ortodoxia mālikī. Nos han llegado afirmaciones de sabios andalusíes de los primeros siglos, que dan a entender que la hegemonía de la doctrina legal de Mālik y sus discípulos (especialmente Ibn al-Qāsim) fue casi total y prácticamente imposibilitó el desarrollo de otras soluciones jurídicas diferentes de las traídas aquí por los padres del mālikismo andalusí. Un jurista de los pri-

\footnotetext{
${ }^{1}$ Me he ocupado de este punto en mi trabajo «Acerca del influjo de la jurisprudencia andalusí en el Magrib», Revista del Instituto Egipcio de Estudios Islámicos, 26 (1993-94), 138-9. El 'amal andalusí ha sido también estudiado por Chalmeta Gendrón, P., quien, en «Acerca del 'amal en al-Andalus: algunos casos concretos», Anuario de Historia del Derecho Español, 57 (1987), 339-364, ha establecido la lista de los datos al respecto que aparecen en el K. al-Wațā'iq wa-l-siŷillāt de Ibn al-'Aț̣ār.

${ }^{2}$ López Ortiz, J., «La recepción de la escuela malequí en España», Anuario de Historia del Derecho Español, 7 (1930), p. 160.
} 
meros tiempos como Ibn Bašī (m. 198/814) afirmaba que si alguien emitía un dictamen (fatwà) apoyándose en una doctrina contraria a la transmitida por Ibn al-Qāsim se hacía merecedor de la desaprobación general y era considerado de criterio poco fiable. Al-Išīlī (autor que no he podido identificar con exactitud) señalaba que, entre los alfaquíes de al-Andalus, «estaba prohibido (mamnū ')» que un cadí escogiera, para fundamentar alguna de sus sentencias, una doctrina legal que no fuera la de Mālik.

Algo más matizada es la visión del cadí Muḥammad b. Ayyūb b. Bassām (m. después de 1126), quien afirmaba que, en época de los grandes maestros (al-šuyüj), éstos permitieron seguir opiniones distintas de las de Mālik, aunque termina diciendo que, después de ellos, se llegó a la situación de que ningún dictamen jurídico se atenía en al-Andalus a otra doctrina que no fuese la de Mālik, y, además, tal como ésta fue transmitida por Ibn al-Qāsim ${ }^{3}$.

Así pues, «nuestra» supuesta singularidad se vio casi siempre reducida a aprovechar las discrepancias entre los propios transmisores de las enseñanzas de Mālik, que a veces le atribuían respuestas dispares a una misma cuestión, o a proponer soluciones a casos que no constaba que Mālik o Ibn al-Qāsim hubieran previsto. Pero, en algunas ocasiones, las fuentes nos hablan de la existencia en al-Andalus de prácticas legales no conformes con la doctrina de Mālik, es decir, con la doctrina unánimemente aceptada como suya. No fueron muchos los puntos de discrepancia con Mālik, pero ese dato llamó tanto la atención que son numerosas las fuentes que lo mencionan, al igual que se menciona también en varias ocasiones el hecho de que existiesen unas cuantas cuestiones en que los andalusíes no siguieron los criterios del principal de los discípulos de Mālik y el más cualificado transmisor de su doctrina: Ibn al-Qāsim.

\section{EL TEXTO ATRIBUIDO A AL-GARNĀṬī}

Una de las listas que contenían tales divergencias es la que López Ortiz encontró en un brevísimo texto árabe que él dio a conocer en $1930^{4}$, y que ha sido de nuevo editado por J. Aguilera Pleguezuelo en $1987^{5}$. Se trata de

${ }^{3}$ Estas tres citas proceden de al-Ša ${ }^{\circ} \mathrm{bi}, A h k a ̈ m$, ed. S. Haloui, Beyrut, 1992, p. 114, núm. 97.

${ }^{4}$ Ed. y trad. en «Recepción...», pp. 162-7.

5 «Manuscrito núm. 1.077, en lengua árabe, de la Biblioteca del Real Monasterio de El Escorial, sin título, del que es autor el jurista granadino y juez de Mallorca Abū Ishāq Ibrāhīm Ibn 'Abd al-Rahmmān al-Garnātī del siglo xIV», Miscelánea de Estudios Árabes y Hebraicos, 36 (1987), 7-20. En este trabajo J. Aguilera edita y traduce los dos primeros folios y el último del manuscrito. En el último folio está el texto que aquí nos interesa. 
una concisa enumeración (apenas una página) de 22 cuestiones jurídicas: cuatro cuestiones en que los andalusíes no siguieron la doctrina de Mālik, y otras dieciocho en que se apartaron de la de Ibn al-Qāsim. El autor del opúsculo sería, según J. López Ortiz, Ibrāhīm b. al-Hāâŷy Aḥmad b. 'Abd alRaḥmān b. 'Uțmān al-Anșārī. Este alfaquí, conocido por al-Garnātịi, nació en Granada en 1102 y ejerció el cadiazgo en diversas regiones, siendo la última la de Mallorca bajo administración almorávide; fue famoso por sus enseñanzas y escritos, y considerado muŷtahid; murió en $1183^{6}$. Aguilera también tiene a este sabio por autor del texto $\mathrm{y}$, como se ha visto ${ }^{7}$, afirma que Abū Isḥāq vivió en el siglo XIv, sin indicar en qué fuente se basa, aunque quizá sea la fecha que él lee en el colofón del manuscrito la que le induce a creerlo así.

La razón por la que López Ortiz y Aguilera Pleguezuelo consideran al cadí de Mallorca autor de tal texto es el hecho de que este documento se halla incluido, como último fașl o apartado, en una obra de Abū Isḥāq conservada en la biblioteca de El Escorial, concretamente en el códice número 1.077 (Casiri, 1072) ${ }^{8}$. Sin embargo, el mismo escueto documento aparece, también a modo de Apéndice, al final del Mufid li-l-hukkām del cordobés Ibn Hisãm (m. 606/1209) ${ }^{9}$. El que esté incluido en todas sus copias descarta que se trate de la iniciativa de algún copista, o el deseo de algún propietario de ver enriquecido su ejemplar con tal texto. Además, está colocado antes del colofón, y sin apenas variantes entre las diferentes copias, mientras que entre dicho apéndice del Mufid y el texto de Abū Isḥāq hay divergencias notables: por una parte, ambos escritos ofrecen numerosas variantes de redacción, que no alteran el contenido, aunque a veces lo completan; por otra parte, Ibn Hisām omite cuatro de los párrafos que aparecen en el docu-

${ }^{6}$ Sobre este sabio, véase Takmila, ed. Cheneb, núm. 400, p. 190; cfr. Al-Nubāhī, AlMarqaba al- 'Ulyā, ed. E. Lévi-Provençal, El Cairo, 1948, pp. 116-7. La contradicción entre ambas fuentes ya fue aclarada por A. Cuellas Marqués en su tesis doctoral sobre la Marqaba al'Ulyā, Universidad de Granada, 1984, p. 400, nota 651.

${ }^{7}$ En nota 5.

${ }^{8}$ Puede verse la descripción de dicho códice en García-Arenal, M., «Algunos manuscritos de fiqh andalusíes y norteafricanos...», Al-Qanțara, I (1980), 11-12.

9 Sobre este autor y su obra, véase mi trabajo «Ibn Hišãm al-Qurțubī y su Mufíd li-l-hnkkām», Quaderni di Studi Arabi, 5-6 (1987-8), 120-139. En mi tesis doctoral (Granada, 1986) traduje los dos primeros kutub o capítulos del Mufid. Además, he traducido pasajes de esta obra en «Los àdāb al-qudāt...», Homenaje al profesor Juan Torres Fontes, I, Murcia, 1987, 235-243; «La correspondencia oficial entre jueces en el Mufid de Ibn Hisām de Córdoba», Homenaje al profesor Bosch Vilá, Granada, 1991, 497-509; «Contribución al estudio de la doctrina jurídica acerca del gaṣb en el Occidente islámico medieval», Actas del III Coloquio Hispano-Marroquí (en prensa); «La preclusión ( $t a$ ' $y \hat{i} z)$ en el derecho procesal mālikī: un texto del Mufid de Ibn Hisām», Homenaje al profesor Justel Calabozo (en prensa). 
mento del cadí de Mallorca, añadiendo, por el contrario, un párrafo final que no se halla en el texto editado por López Ortiz.

Por tanto, habida cuenta de las numerosas omisiones, descartamos que el autor de tal texto pueda ser el mismo que el del Mufíd, que además no lo incluye en el «Sumario» que coloca al principio de su obra. Pero, quizá, tampoco lo sea Abū Ishạā. Tengamos en cuenta que, cuando López Ortiz le atribuyó la paternidad del escrito, desconocía que éste se encontrara igualmente en otro códice. También al-Nubāhī (ob. post 1390) cita, con las mismas palabras que en el Mufid y en el faṣl del granadino, las cuatro cuestiones en que los andalusíes no siguieron la doctrina de Mālik, pero no nombra ni a Abū Ishạāq ni a ningún otro como su autor ${ }^{10}$. Hay un dato que me parece muy de tener en cuenta a la hora de dilucidar si al-Garnāți puede ser autor de tal texto, y es el hecho de que él mismo alude en el citado manuscrito (folio 220a) a la cuestión de las divergencias que los andalusíes tuvieron con respecto al madhab de Mālik, y él dice allí que dichas divergencias fueron seis (añade una cuestión sobre la llamada del $m u^{\prime} a \underline{d} \underline{d}$ in y otra sobre el reparto del botín) y no sólo cuatro, como se dice en el texto incluido al final del manuscrito que contiene su opúsculo.

Tanto J. López Ortiz como J. Aguilera y otros arabistas han visto en este documento una lista de las peculiaridades que caracterizaron a la jurisprudencia andalusí a lo largo de toda su historia. Sin embargo, los verbos principales del texto están en pasado. López Ortiz traduce: «Cuestiones en las que se separan los españoles de la escuela de Mālik», infiriendo que tales peculiaridades jurídicas caracterizaron todo el período andalusí; pero el texto, sin duda escrito antes del siglo XIII, dice: al-masä’il allatī jālafa fí-hā al-andalusiyyūn madhab Mãlik, "cuestiones en que se separaron los andalusíes...». No se dice, por ejemplo, «dan por válido...», sino «dieron por válido...», etc. Y, además, el sujeto de estos verbos es una tercera persona del plural («los andalusíes») y no la primera del plural. Lo que, a mi modo de ver, quiere decir que o bien el texto está escrito fuera de al-Andalus, o bien se alude en él a andalusíes de tiempos pretéritos. Me inclino por lo segundo, siguiendo a al-Nubāhī, quien dice: «Las cuatro cuestiones en que los habitantes de al-Andalus se apartaron antiguamente (qadi $m^{a n}$ ) de la doctrina

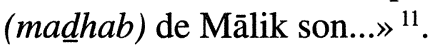

No considero lógico que ningún andalusí, al describir la práctica jurídica de su época, diga, por ejemplo: «Los andalusíes no admitieron...» Aunque

${ }^{10}$ Al-Marqaba al-'Ulyā, p. 51 (pp. 115-6 de la citada tesis de A. Cuellas).

${ }^{11}$ Ibidem. 
cabe la posibilidad de que lo que en aquellos primeros tiempos no fue admitido siguiera después sin serlo, o que una norma contraria al parecer de Mālik o de Ibn al-Qāsim, que estuviera vigentes entonces, haya continuado en vigor durante toda o la mayor parte de la historia de al-Andalus. Pero, en todo caso, lo único que allí está explícitamente dicho es que tal singularidad fue característica del fiqh cordobés «antiguamente», por emplear la expresión de al-Nubāhī.

Así pues, el constatar que el texto se refiere a la doctrina de los introductores de la doctrina mālikī en al-Andalus nos plantea el siguiente interrogante: ¿pervivieron todas o algunas de estas particularidades a lo largo de la historia hispano-arabe? Las páginas que siguen son el fruto de mi búsqueda por algunas colecciones de jurisprudencia andalusí intentando responder a esa pregunta. El lector podrá comprobar que la fortuna de tales «peculiaridades» ha sido varia. Veremos cómo antiguos debates fueron superados y algún que otro 'amal no fue mantenido, y también lo contrario.

Sobre todo en el caso de una práctica jurídica en desuso o casi olvidada, cabe plantearse la pregunta de cuál era el interés de recordar tal discrepancia en textos que no parecen de mera erudición, sino de derecho aplicado. Creo que la respuesta se halla en un pasaje de los Aḥkäm de al-Sa'bī (402/1012497/1104) en que este autor cita otros Ahkām, los de Ibn Ziyād (m. 312/924) ${ }^{12}$, donde se alude (como en tantas otras fuentes) a la controversia sobre si era lícito corroborar con juramento el testimonio de una sola persona. Y se concluye: «Discreparon los juristas acerca de la licitud de sentenciar en base a ello, y si los juristas discrepan acerca de algo, el juez tiene la opción de atenerse a la opinión de quien mejor le parezca, según su propio razonamiento ('alà l-î̀tihād). Así lo dijo Ibn Lubāba»' ${ }^{13}$.

Ofrezco a continuación mi edición del breve texto atribuido a Abū Ishāq al-Garnāțī. Aunque éste ya fue editado por J. López Ortiz ${ }^{14}$, dicha edición contiene algunas erratas. Posteriormente, como ya he mencionado, este texto fue objeto de otra edición por parte de J. Aguilera Pleguezuelo, edición que corrige las erratas que aparecen en el trabajo de López Ortiz ${ }^{15}$, pero des-

\footnotetext{
${ }^{12}$ Se trata del cadí de Córdoba Ahmad b. Ziyād, al-Habīb, que reunió «un conjunto de sentencias $(a h h a \bar{m})$ para consulta e instrucción de alfaquíes y cadíes (...) es la obra conocida como Ahkām Ibn Ziyād, que es una de las principales fuentes de los Ahkām al-Kubrà de Ibn Sahl» (Fierro, M. I., «Tres familias andalusíes de época omeya apodadas Banū Ziyād», Estudios Onomástico Biográficos de al-Andalus, V, p. 124).

${ }^{13}$ Al-Ša ‘bì, Ahkäm, p. 114, núm. 96.

14 Véase nota 4.

${ }^{15}$ Salvo en un punto, ambos leen hawli $q$ (sic) en lugar de hawlayn.
} 
graciadamente en su publicación faltan las últimas líneas del manuscrito. Era necesaria, pues, una edición completa del texto, que señalara las variantes más significativas de las dos fuentes de que por ahora disponemos (el ms. 1077 de El Escorial y los diversos mss. del Mufid). Tras el texto árabe incluyo mi traducción de cada párrafo o cuestión, seguida de la jurisprudencia al respecto que he hallado en mi investigación.

EDICION DEL TEXTO ATRIBUIDO A AL-GARNĀṬT

خـالف أهـل الأندلس مـذهب مـالك (رحمـهـ اله) في أربــع مسـائل وهـي ${ }^{16}$ : ألا

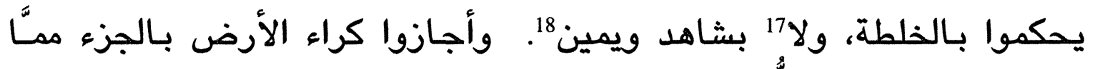
يخرج منهـا، وذلك كلهّه المساجد وهو مذهب الأوزاعي.

وخالفوا مذهب ابن القاسم في ${ }^{20}$ ثماني عشرة مسألة وهي: مراعاة الكفوء

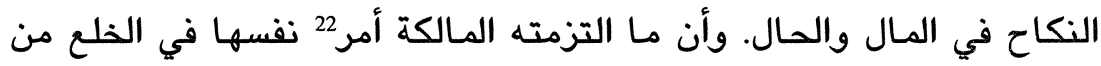

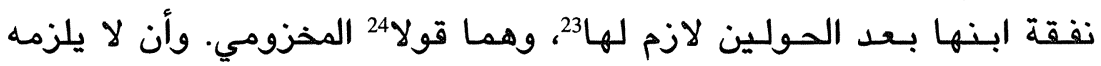

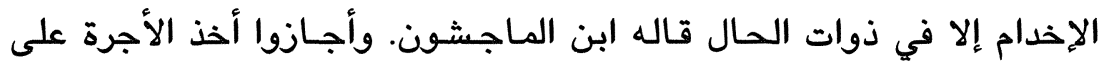

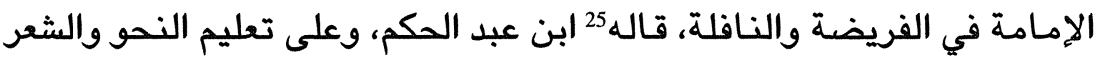

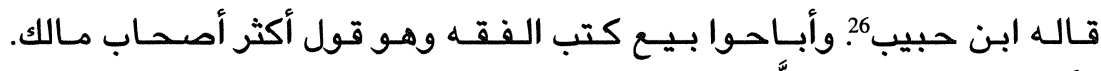

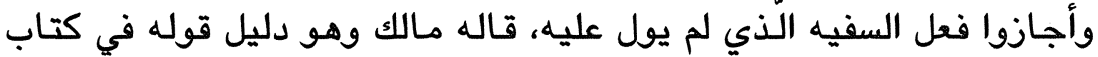

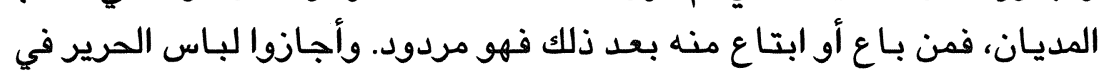

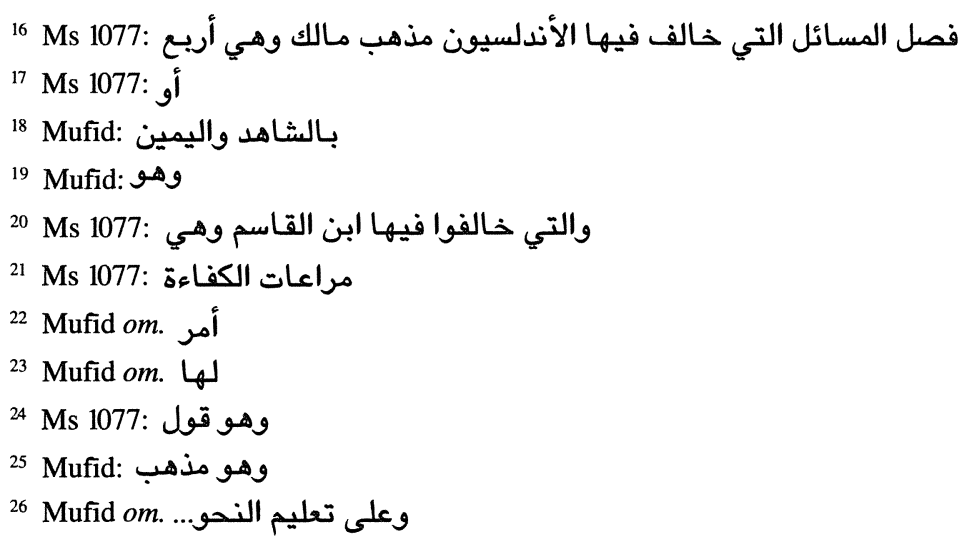




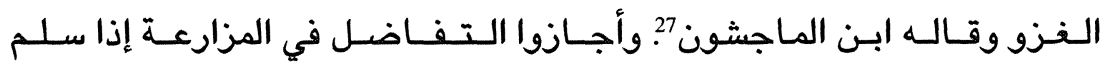

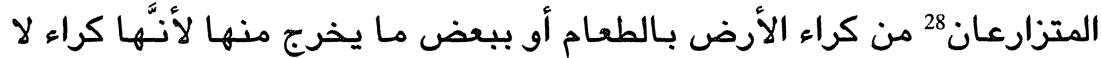

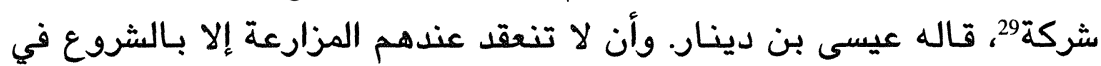

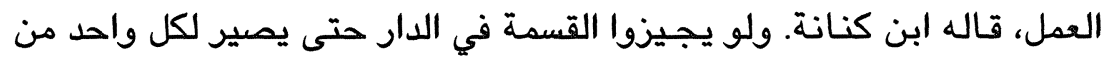

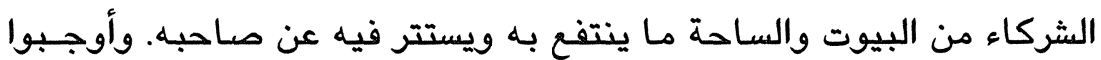

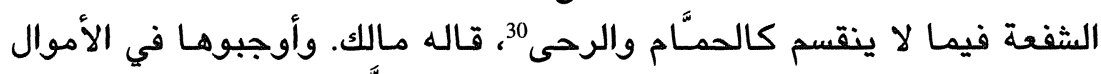

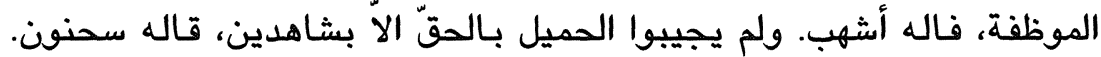

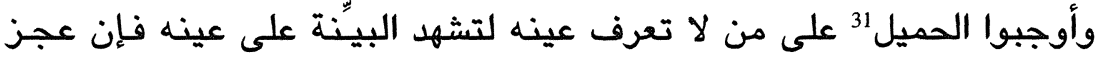

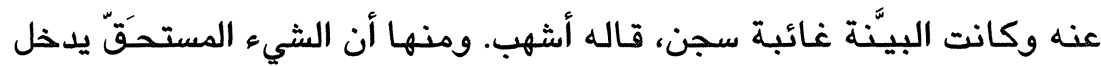

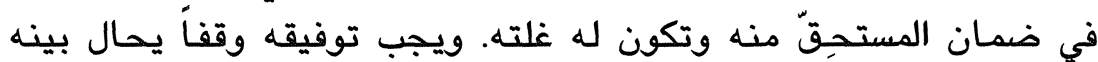

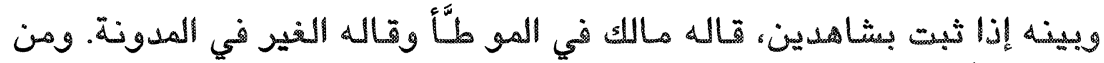

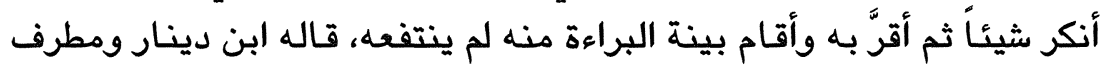

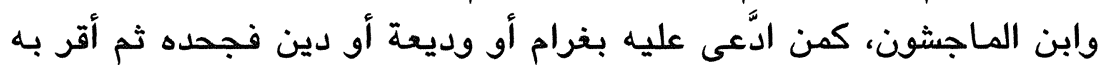

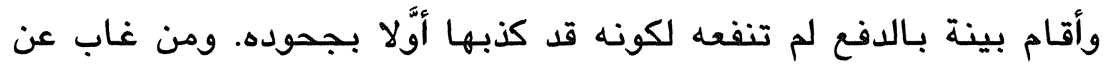

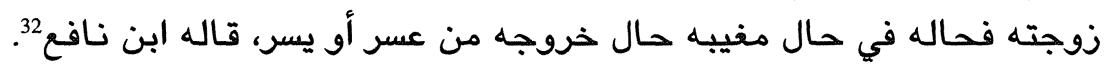

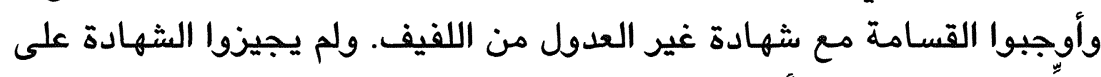

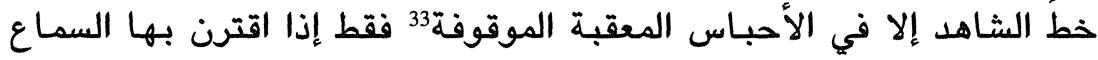

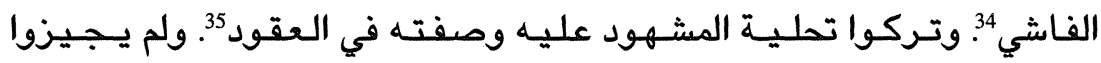

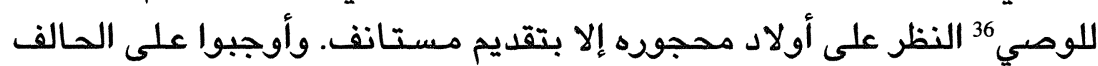

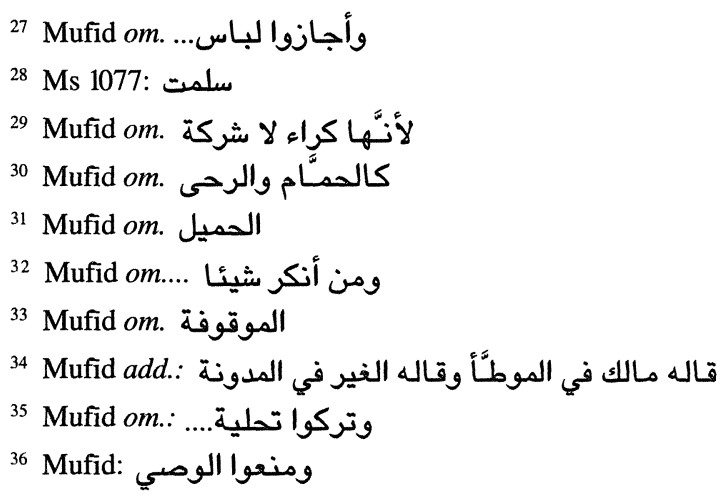




$$
\text { إذا وجبت علبه اليمين أن يحلف قائماً متوجه القبلة، وقاله ابن الماجشون ويه }
$$

\section{TRADUCCION Y COMENTARIO*}

\section{LAS CUATRO CUESTIONES EN QUE SE APARTARON DE MĀLIK}

1. No tomaban en consideración, cuando juzgaban un pleito, la existencia de relaciones mercantiles previas $(j u l t a)^{38}$.

Se entiende por julta, en este contexto, la «relación habitual de negocios o intereses, entre dos personas». De acuerdo con la doctrina mediní, es requerida la existencia de tal relación entre actor y demandado para poder deferir el juramento decisorio a este último ${ }^{39}$. Dicha doctrina se basa en una tradición que consta en el Muwațta' ${ }^{40}$, según la cual si 'Umar b. 'Abd al-'Azīz advertía que había entre demandante y demandado relaciones mercantiles frecuentes (mujālața), tomaba juramento al demandado; en caso contrario, no. Así pues, si un querellante no pudiese aportar pruebas, ni tampoco justificar transacciones mercantiles habituales entre él y el demandado, no podría deferirle el juramento denegatorio, con lo que la causa sería sobreseída.

En el formulario de Ibn al- Atțār (330/942-399/1009) ${ }^{41}$ encontramos un modelo de documento para dar fe de la existencia de las relaciones llamadas mujālața «que hacen - según allí se dice- obligatorio el juramento de acuerdo con la doctrina de Mālik, quien opinaba que no había obligación de prestarlo si no se probaba que existía julta». En su comentario a este formulario, Ibn al- 'Aț̣ār no dice que fuera otro el usus fori en al-Andalus, ni siquiera menciona otra doctrina legal distinta de ésta; pero el hecho de que en el largo título de esa wațīqa un jurista mālikī como Ibn al- 'Atțār deje dicho que tal procedimiento notarial se acoge a la doctrina de Mālik parece indicar que existía o había existido un ijtiläf, otra posibilidad legal, que sería, sin duda, no tomar en consideración la existencia o no de julța.

En el siglo XI el malagueño al-Sa‘bī (m. 497/1103) expone cuál es el pro-

37 Ms 1077 om.: .... وأوجبوا على الحالف

* La traducción de los párrafos del texto va en negrita y, a continuación, mi comentario.

${ }^{38}$ Para otra interpretación, completamente diferente, de esta frase, cfr. Fierro, M. I., «Los mālikíes de Al-Andalus y los dos árbitros (al-hakamāni)», Al-Qanțara, VI (1985), p. 79 y nota 2.

${ }^{39}$ Véase Santillana, Istituzioni di Diritto musulmano..., Roma, 1925-38, p. 627.

${ }^{40}$ Beirut, 1988, t. II, pp. 103-4, núm. 11.

${ }^{41}$ K. al-Wata'iq wa-l-siyillät, ed. P. Chalmeta y F. Corriente, Madrid, 1983, p. 323. 
cedimiento que le parece más conveniente en este punto diciendo: «Si el demandado es persona de orden, no se le puede obligar a prestar juramento, a no ser que haya julta; pero si fuera alguien que no aparentara ser persona de respeto, entonces deberá prestar juramento, aunque no haya julta» ${ }^{42}$. Por tanto, al menos en una circunstancia sí consta que en esa época era tomada en consideración la julța.

Los tratados jurídicos andalusíes de época califal o posteriores ${ }^{43}$, a diferencia de lo que se dice en el texto en cuestión, no sólo no ignoran la julța, sino que se preocupan por garantizar en qué circunstancias habrá de ser tomada en consideración, haciendo suya la doctrina de Aṣbag según la cual «la existencia de una relación habitual de negocios o intereses (julța) sólo puede ser tenida en cuenta a partir de intercambios repetidos» ${ }^{44}$, y dan normas sobre cómo probar dicha relación. Como explica Averroes en su Bidāya ${ }^{45}$, era ésa una doctrina de Mālik y de los siete juristas (fuqahà') de Medina, mientras que la generalidad de los teóricos de otras escuelas sostenían que el demandado debía jurar sin esperar a que el demandante probara que existía julța entre ellos. Pero no menciona Averroes en absoluto que ésta última fuera también la norma en al-Andalus, con lo que parece darnos a entender que, al menos los tribunales andalusíes de su época (s. XII), tomaban en consideración la julta.

\section{Ni admitían el juramento en apoyo de un testimonio insuficiente.}

Tal medio de prueba —es decir, el testimonio único corroborado por el juramento de quien se beneficia de ese testimonio- es admitido en las cuestiones patrimoniales no sólo por Mālik y los mediníes, sino también por los fundadores de otras dos corrientes jurídicas: al-Săfi‘ī e Ibn Ḥanbal. Por el contrario, le niegan validez, en cualquier causa, Abū Ḥanīfa, al-Awzā‘ī y alLayt ${ }^{46}$. Y es esta segunda opinión la que siguen en al-Andalus destacados alfaquíes de los primeros tiempos de la dinastía omeya; por ejemplo, de un cadí que conoció a Mãlik, Muḥammad b. Bašīr (m. 814) se dice en la Mar$q a b a$ (p. 50) que «no era partidario de sentenciar en base al juramento en

42 Ahkäm, p. 223 , núm. 376.

${ }^{43}$ Por ejemplo, el Kitāb muntajab al-ahkām de Ibn Abī Zamanīn, Estudio, traducción y edición crítica del sumario y del libro I, tesis doctoral de M. Arcas Campoy (Granada, 1982), I, núm. 10, y el Mufid li-l-hukkām, de Ibn Hisām (Estudio preliminar, edición crítica y traducción..., tesis doctoral de A. Carmona González, Granada, 1986), f. ${ }^{\circ} 9$ a del ms. del Sacromonte.

44 Mufid, f. ${ }^{\circ} 9$ a.

45 Ed. El Cairo, 1394-1974, t. II, p. 506.

46 Así consta en la Bidāya, II, p. 501. 
apoyo de un solo testigo (...), aunque Mālik sí era partidario de ello». Entre los padres del mālikismo andalusí, consta el rechazo de tal práctica por parte de Yahyyà b. Yahyà al-Layțī (m. 234/849) ${ }^{47}$; sin embargo, Ibn Habīb se mostraba partidario de poder adjudicar un derecho «en base a un testigo y un juramento», y transmitió los hadices en que se apoyaba tal práctica y la doctrina de Mālik al respecto ${ }^{48}$.

Ya en tiempos de Ibn Lubāba (225/840-314/926), junto a los jueces que en este punto todavía se atenían a la práctica tradicional andalusí (vigente «desde que entraron los árabes en este país»), había otros que se inclinaban por aplicar la doctrina de Mālik y sus seguidores. Así se desprende, a mi juicio, de una fatwà de Muhammad b. Lubāba ${ }^{49}$, en que este jurisconsulto deja libertad al cadí para seguir uno u otro criterio. En cuanto a él mismo, se confiesa indeciso al respecto, «dada la corrupción de la gente y la poca fiabilidad del testimonio», con lo que aparentemente nos quiere decir que el testimonio único, aun corroborado con juramento, no le ofrecía suficientes garantías como prueba decisoria.

Más adelante, en época califal, el alfaquí Abū Ibrāhīm (m. 352/963 ó 354/965) fue consultado acerca de las críticas que algunos seguidores de Ibn $\operatorname{Masarra}^{50}$ (m. 319/931) hacen a los alfaquíes de al-Andalus en dos puntos muy concretos: la cuestión de «los dos árbitros» ${ }^{51}$ y la del testimonio insuficiente corroborado con juramento. Los seguidores de Ibn Masarra consideraban que, en el primer caso, se desobedecía un precepto coránico, y en el segundo se ignoraba una tradición que procedía del propio Mahoma, pues se tenía por cierto que el Profeta había admitido, en un litigio que hubo de dirimir, la validez del testimonio único acompañado de juramento. En su respuesta Abū Ibrāhīm defiende decididamente los argumentos en que se basaron aquellos primeros mālikíes de al-Andalus, pero no nos dice nada sobre la práctica judicial en su época respecto al testimonio de un solo testigo corroborado con juramento. Reconoce que tal costumbre era el usus fori habitual en Medina y en el Hịyāā, aunque no estaba legitimada por un isnād fiable (lä bi-șịhhat alisnād), pues no se había hallado una cadena de transmisores que llegase al Profeta ni a ninguno de los cuatro primeros califas. Lo más atrás que se habían

${ }^{47}$ Véase Fierro, M. I., «Los mālikíes de al-Andalus y los dos árbitros (al-ḥakamānī)», AlQantara VI (1985), p. 80, nota 8.

48 Al-Nubāhī, Marqaba, p. 50.

${ }^{49}$ Reproducida por Ibn Ziyād en sus Ahkäm y parcialmente citada en la Marqaba, p. 50.

${ }^{50}$ En el texto se lee «Ibn Maysara».

${ }_{51}$ Véase Fierro, M. I., «Los dos árbitros...», 79-102; sobre el mušāwar toledano Abū Ibrāhìm, véase ibidem, 89-92. 
podido remontar los tradicionistas era a un escrito de 'Umar b. 'Abd al-'Azìz (que fue califa de 717 a 720) en que ordenaba a 'Abd al-Hamīd b. 'Abd alRaḥmān que admitiera ese tipo de prueba. Sin embargo, los seguidores iraquíes de Mālik rechazaron tal práctica argumentando que ni se encontraba en el Libro de Dios, ni era un hadī $\underline{t}$ auténtico fuera de toda duda, ni había constancia de que hubiera sido aprobada por ninguno de los cuatro primeros califas ${ }^{52}$.

Del siglo XI he encontrado dos testimonios a este respecto: el del cordobés Ibn Fajjār (m. 1028) y el de Ibn 'Attāb (383/994-462/1069). El primero de ellos se muestra, con reservas, partidario de aceptar el testimonio único acompañado de juramento. Pero afirma que los expertos en la tradición discrepaban en cuanto a la autenticidad (țubūt) del hadīt que permitía que el juramento completara un testimonio insuficiente ${ }^{53}$. En cuanto a Ibn 'Attāb, en la biografía que Ibn Baškuwāl ${ }^{54}$ le dedica, señala: «Decía respecto al abandono entre nosotros de la norma que permite adjudicar un derecho en base a un testimonio único corroborado con juramento: 'Si encontrase a alguien que juzgara aplicando esa norma, mi dictamen jurídico sería favorable a él en eso (law waŷadtu man yaqdi bi-dalika la-aftaytu-hu bi-hi)'».

En tiempos de Ibn Rušd, el Abuelo, la doctrina de Mālik a este respecto parece ya muy seguida en al-Andalus, tal como se desprende de algunas de las consultas que se le hacen al célebre alfaquí cordobés ${ }^{55}$; pero no del todo: así se constata en uno de sus dictámenes ${ }^{56}$, en que Ibn Rušd se dirige a un cadí que le consulta, diciéndole: «Si eres de los que admiten como prueba el testimonio único corroborado con juramento, basándote en lo que nos ha llegado acerca de esto del profeta (...); pero, si no fuera doctrina admitida por ti la de sentenciar favorablemente en base a un testigo más juramento, según la práctica que adquirió vigencia entre nosotros ('alà mã ŷarà bi-hi l-'amal 'inda-nā)...”.

Siguiendo en esta misma época almorávide, existe otro testimonio: el del propio Abū Isḥāq al-Garnāṭ̂̄ (el cadí a quien se ha atribuido la paternidad del documento que examinamos), quien se muestra contrario a aceptar que un testimonio único pudiera ser validado como prueba suficiente mediante un juramento ${ }^{57}$.

${ }^{52}$ Apud al-Sa'bī, Ahkàm, pp. 193-5 (núms. 285-6).

${ }^{53}$ Apud al-Š'bì, Ahkàm, p. 186, núm. 272.

${ }^{54}$ Al-Ṣila, ed. de El Cairo, p. 546, núm. 1194.

55 Véase Ibn Rusd, Fatāwà, ed. al-Mujtār b. al-Ṭăhir al-Talīì, Beyrut, 1987, p. 1145, núm. 356 y pp. 1161-4, núm. 367.

${ }_{56}$ Fatāwà, pp. 1416-7, núm. 517.

57 Folio 220a del ms. 1077 de El Escorial. 
Más tarde, a finales del siglo XII, el Mufid afirma que el juramento de la parte beneficiada en apoyo de un testimonio insuficiente era una práctica admitida al menos en las causas patrimoniales, y da normas sobre cómo y cuándo aceptar su legitimidad ${ }^{58}$.

\section{Reputaron lícito pagar el precio del arrendamiento de tierras con una determinada parte de los frutos obtenidos de ellas. Esto y lo an- terior es doctrina de Layt $\mathbf{b}$. Sa $\mathbf{S d}^{59}$.}

En el Muwatța' ${ }^{60}$ Mālik afirma que es condenable (makrūh) la práctica que consiste en ceder una tierra baydă', es decir, una tierra en que no hay nada sembrado, a cambio del tercio o de la cuarta parte de lo que produzca, pues este contrato es aleatorio por el riesgo que comporta ya que la contraprestación es incierta. En el formulario de Ibn Mugit ${ }^{61}$ (m. 459/1067) aparece prohibido - a partir de un hadiz del profeta- el contrato llamado mujābara, que consiste en «arrendar la tierra a cambio de parte de lo que produzca». Tal práctica no debió de ser aceptada legalmente durante mucho tiempo, pues, aunque se admitió en al-Andalus cierta discrepancia en cuanto a si el arriendo de un terreno podía pagarse con productos de esa misma tierra (como digo a continuación), en lo que todos los juristas, al menos a partir del siglo $\mathrm{x}$, estaban de acuerdo era en afirmar que esa cantidad no podía ser nunca una parte proporcional de la cosecha ${ }^{62}$.

En la Mudawwana se afirma ${ }^{63}$ que la tierra no se arrienda a cambio de lo que crece en ella, sean cosas comestibles o no, excepto la leña, las cañas y el sándalo. Por el contrario, 'İsà b. Dīnār (m. 212/827), uno de los padres del mālikismo andalusí, sostenía que era lícito su arriendo a cambio de cosas de cualquier género, exceptuando todo aquello que se vuelve a echar en la tierra y germina. Y había igualmente quienes afirmaban que el único medio de pago válido para el arriendo eran los dinares y los dírhemes. Frente a esta última opinión, Ibn Habīb (m. 238/853) —quizá el más influyente de los tres introductores del mālikismo - aseguraba que ese pago en metálico no era lí-

58 Ibn Hisām, Mufìd, f. ${ }^{\circ} 27 \mathrm{~b}$.

59 Corrijo el original, donde se lee «Sa‘īd».

60 II, p. 78, núm. 14.

61 Ibn Mugīt, Al-Muqni ‘ fi 'ilm al-šurūt, ed. F. J. Aguirre Sádaba, Madrid, 1994, p. 263.

62 Así se dice explícitamente en el Mufid, f. ${ }^{\circ} 162 \mathrm{~b}$.

63 Al-Mudawwana al-Kubrà, ed. El Cairo, 1323-1905, t. XI, p. 185. 
cito. Pero, repetimos, en lo que todos los juristas estaban de acuerdo era en la no-admisibilidad de repartir la cosecha: una determinada parte para el dueño de la tierra y otra para el colono ${ }^{64}$

Pero parece que la práctica social, en lo que respecta a la prohibición de repartir la cosecha, no siempre siguió la doctrina de los alfaquíes, quienes intentaban apartar de ese tipo de contratos a los musulmanes, poniendo en la lista de los réprobos e indignos de ser testigos a quien «arrendara su tierra contra una parte de la cosecha: una sexta, una cuarta, una octava parte o cualquier otra; por más que al hacerlo siga la doctrina de aquellos tradicionistas (ahl al-hadi $\underline{t})^{65}$ que lo permiten, y ello, siempre que supiere que tal práctica no está permitida» ${ }^{66}$. Este anatema indica, sin duda, que existía, más o menos extendida, una práctica social que se intentaba atajar. E indica también que la mayoría de juristas no admitía la licitud de dicha práctica, a pesar de que, por lo que nos dice el texto, fue tenida por válida en cierta época.

Todo ello queda patente en la siguiente fatwà de Ibn Rusd, al-ŶYadd ${ }^{67}$ : le consultaron acerca de alguien que cultivaba la tierra a cambio de un cuarto o de un tercio de la cosecha, en lugar de que el dueño de la tierra le asignara una parte concreta del sembrado (min gayr an yay 'ala la-hu rabb al-ard nași $b^{a n}$ min al-zari ' $\left.a\right)^{68}$, y le preguntaron si ese hecho tan criticable hacía que fuera recusable su testimonio aun en el caso de que ignorara la ilegalidad de aquello. En su respuesta, Ibn Rušd admite de hecho la posibilidad de discrepar de tal prohibición: «Es opinión de algunos (qad qi la) que su testimonio no es válido, al haber contravenido la tradición según la cual 'Abd al-Raḥmān b. 'Awf cedió a Sa'd b. Abī Waqqāṣ una tierra para que la cultivase a cambio de la mitad (del producto) y el profeta le dijo: ¿Deseas incurrir en usura (ribà)?' y prohibió aquello ${ }^{69}$. Lo que nosotros opinamos es que si el labrador actuó así por ignorancia o apoyándose en la interpretación diferente que nos ha llegado (muta'awwilan li-mā ŷa'a fi-hi min al-jilāf)...».

\footnotetext{
${ }^{64}$ Información sacada literalmente del Mufid, f. ${ }^{\circ} 162 \mathrm{~b}$.

65 Sobre los «tradicionistas» puede verse Marín, M., «Bāqī b. Majlad y la introducción del estudio del hadīt en al-Andalus», Al-Qanțara, I (1980), pp. 165 y ss.

${ }^{66}$ Mufid, f. ${ }^{\circ} 12 \mathrm{a}$.

${ }^{67}$ Fatāwà, pp. 1367-6, núm. 486.

${ }^{68}$ Como se verá más adelante, esta otra modalidad sería el contrato de muzära 'a, por el que alguien labra toda la tierra, obteniendo a cambio lo que crece en una parte de ella.

69 Es Saḥnūn quien transmite dicho hadị en la Mudawwana, t. XI, pp. 186-7.
} 
4. Permitieron plantar árboles en las mezquitas, en lo cual siguieron la escuela de al-Awzāoî.

Efectivamente, se sabe que, a final del siglo VIII, «se plantan —según Ibn al-Faradīi 70 _árboles en la mezquita [de Córdoba], conforme a la doctrina de los sirios, cosa que reprobaba Mālik y su escuela»; pero no he encontrado en las fuentes examinadas jurisprudencia alguna respecto a esta cuestion.

\section{LAS «DIECIOCHO» CUESTIONES EN QUE SE APARTARON DE IBN AL-QĀSIM}

En cuanto a las dieciocho cuestiones en que los introductores de la doctrina mālikī en al-Andalus no siguieron los puntos de vista de Ibn al-Qāsim, hay que decir que en realidad son más, pues algunas de esas cuestiones encierran dos o tres aspectos o normas. Por otro lado, en varias de estas cuestiones la divergencia no es sólo con Ibn al-Qāsim, sino también con Mālik, que en realidad aparece en la Mudawwana y en otras fuentes como la autoridad doctrinal que garantiza tales normas. Por ello, me sorprende que esta lista consigne la discrepancia sólo con respecto a Ibn al-Qāsim, que la mayoría de las veces no es más que el transmisor.

Como he hecho en el caso de las «cuatro divergencias», he intentado averiguar si esas normas (que el malikismo andalusí del siglo IX convirtió en reglas aplicadas por los tribunales en base a un consenso local) sobrevivieron en las siguientes generaciones.

\section{La exigencia, al concertar un matrimonio, de igualdad en bienes y en situación.}

A principios del siglo $\mathrm{x}$ el andalusí Ibn 'Abd al-Ra’ūf exigía la igualdad entre los esposos sólo en el aspecto religioso $(d \bar{i} n)$, lo que podría parecer un abandono de la costumbre de los primeros tiempos, y una aceptación de esa mínima exigencia de igualdad, que es la única que aparece en la Mudawwana. La exigencia máxima de igualdad estaría expresada con la fórmula: kafä'at al-dīn wa-l-nasab wa-l-ḥăl wa-l-māl ${ }^{71}$. Sin embargo, Ibn al-“Aț̣ār

70 Ta'rīj 'ulamā' al-Andalus, ed. Codera, p. 208, núm. 608.

${ }^{71}$ Véase Chalmeta, P., «El matrimonio según el $K$. al-Watā'i $i q$ de Ibn al-'Ațtār...», Anaquel de Estudios Árabes, 6 (1995), p. 38 (nota 48). 
(m. 399/1009) ${ }^{72}$ e Ibn Mugīt (m. 459/1068) ${ }^{73}$ nos han dejado constancia de que en su época se exigía una paridad fi l-hâal wa-l-māl. Ibn Mugīt expone que si dos testigos diesen fe de que alguien no fuese de igual rango que la mujer con la que hubiere pactado casarse, el juez debería impedir dicho matrimonio, aunque contara con la aprobación del walī. Este autor proporciona incluso un formulario de atestación para casos semejantes ${ }^{74}$.

Lo mismo opina Ibn Rusd, el Abuelo, a quien le consultaron sobre una joven para quien su madre concertó un matrimonio desventajoso con un marido que no era su parigual (zawŷ gayr kaf'), y afirmó que el matrimonio podía declararse nulo si dos testigos daban fe de la situación del marido ${ }^{75}$.

2. Si una mujer dueña de su persona se hubiera obligado, para obtener el divorcio consensuado $\left(j u l^{`}\right.$ ), a asumir la manutención de su hijo después de cumplidos los dos años, tal cláusula sería válida y vinculante. Esta norma y la anterior siguen la doctrina de al-Majzümï.

En el siglo XI al-Sa ‘bī (m. 497/1102) afirma que el hecho de que la mujer asumiera la manutención de su hijo después de los dos años normales de lactancia, descargando de esa obligación al marido, era una práctica admitida en al-Andalus ${ }^{76}$. Lo mismo sucedía en época de Ibn Rušd al-Ŷ add; también entonces se seguía admitiendo en al-Andalus que una mujer obtuviera su divorcio aceptando como condición su compromiso a asumir la manutención de su hijo más allá de los dos años de lactancia. Así se deduce de una consulta que se le hace, en que ni consultante ni mufti ponen en duda la legalidad de tal cláusula ${ }^{77}$.

En su comentario a esta fatwà de Ibn Rušd, al-Jațạāb dice ${ }^{78}:$ «Este dictamen se basa en la doctrina ( $q a w l$ ), que considera lícito el divorcio jul ‘ con la condición de que la mujer se comprometa a asumir la manutención del niño después del período de lactancia. Tal es la doctrina de Ašab, Ibn Nãfi", Saḥnūn, Ibn al-Māŷišūn y al-Majzūmī. Y, según Ibn 'Arafa, es también la opinión de al-Mugīra y de todos los orientales (mašriqiyyūn). Dice Ibn

${ }^{72}$ K. al-Watâa'iq, p. 12.

${ }^{73}$ Ibn Mugīt, al-Muqni', p. 52.

${ }^{74}$ Ibn Mugit, al-Muqni', p. 52.

${ }^{75}$ Fatāwà, pp. 283-4, núm. 51.

${ }^{76}$ Al-Sa'bì, Ahkäm, p. 115, núm. 99.

${ }^{77}$ Fatāwà, p. 1277, núm. 428.

${ }^{78}$ El texto de al-Jatțāb ha sido incluido en nota a pie de página (p. 1277) por el editor de las Fatāwà de Ibn Rušd. 
Habīb: 'Es la doctrina que seguimos nosotros y la generalidad de la gente, y la que sostuvo también Ibn Dīnār'. Dice Ibn Salmūn: 'Sobre esta doctrina se creó la práctica judicial'. Dice Ibn Sahl: «Nuestra práctica se atiene a la doctrina de Sahnūn y de quienes lo siguen en eso, y apoyándose en ella se emitieron fatwà-s que aprobaban la separación amistosa de los esposos con la condición de que la mujer o cualquier otra persona se comprometiera a la manutención del niño más allá de los años de la lactancia. Y en base a ello redactaron los notarios sus documentos. Pero, en cambio, la doctrina de Mālik y la de Ibn al-Qāsim es que tal cláusula no es lícita'.»

3. Y no consideraban vinculante para el marido la cláusula por la que se obliga a proporcionar servidumbre a la esposa, excepto en el caso de que ella fuera persona que lo requiriese por su condición ${ }^{79}$. Seguían en ello la opinión de Ibn al-Mâŷišūn.

La cláusula por la que el marido se obliga a proporcionar servidumbre $(i j d a \bar{m})^{80}$ a la esposa en el supuesto de que ella fuera «de las que no se sirven a sí mismas» ${ }^{81}$ fue objeto de debate entre los alfaquíes a lo largo de la Edad Media. Se debatió si era una cláusula lícita o si, por el contrario, anulaba el contrato matrimonial en caso de ser incluida en él antes de la consumación del matrimonio; entre los que admitían su licitud, se discutió si era una cláusula de inclusión obligatoria en el supuesto contemplado en el texto, o si no era, aun en este caso, nada más que una estipulación voluntaria y, por último, estaba el ijtiläf que consta aquí, es decir, si una vez incluida en el contrato era de obligado cumplimiento en toda circunstancia.

El cadí 'Iyāạ, en una consulta que realizó a Ibn Rušd en 519/1125, le pregunta acerca de qué le parecía la opinión de algunos «modernos» $(m u-$ ta'ajjirin) que consideraban ilícita tal cláusula. En el texto de su pregunta, 'Iyāọ dice haber visto que Ibn al-Hindī (m. 399/1008) consideraba lícita dicha estipulación y que ni siquiera mencionaba que fuese una estipulación voluntaria, mientras que Ibn al- ‘Aț̣ạar veía más acertado que fuera volun-

\footnotetext{
${ }^{79}$ El texto dice: illa fi da dawät al-hăl, lo que queda explicado en el modelo de contrato matrimonial de Ibn Mugît, donde se lee: anna-hā majdūma li-ḥăli-hā wa-manșibi-hā (Muqni', ed. F. J. Aguirre, p. 22).

${ }^{80}$ López Ortiz leyó esta palabra como ajdām y vio en ella un hipotético plural de jādim, y dice: «El texto indica una pluralidad de personas afectas al servicio de la mujer; en esta pluralidad está la oposición con la doctrina de Abenalcasim» («Recepción», p. 163, nota 850).

${ }_{81}$ Ésta es la expresión que emplean Ibn al-'Atțāar e Ibn Mugìt en sus modelos de contrato matrimonial.
} 
taria. (En efecto, en el primer modelo de contrato matrimonial que figura en el formulario de Ibn al- 'Atțār esta cláusula aparece entre las voluntarias) ${ }^{82}$. En su respuesta, Ibn Rušd aduce una cita de Ibn Habīb según la cual el marido está obligado al ijdām si tiene medios para ello y si la esposa es de las que lo requieren por su condición y, si él no tuviera medios, no le obliga tal cláusula, aunque ella sea de las que siempre han sido servidas. Ahora bien —continúa diciendo Ibn Habīb-, si ella no es de esa categoría, no tiene él obligación de proporcionarle servicio doméstico, aunque tuviera medios para ello ${ }^{83}$. Es este último punto el que no admitía Ibn alQāsim.

Por tanto, para eludir la obligación del cumplimiento de dicha cláusula, sería preciso probar que la esposa no tenía la categoría requerida. Es, sin duda, para evitar tales contenciosos, por lo que Ibn al-'Atțār, en el modelo de contrato matrimonial ya mencionado, hace preceder dicha estipulación de dos reconocimientos explícitos por parte del esposo: 1) él queda enterado de que su mujer es de las que no se sirven a sí mismas, y 2) él afirma tener medios suficientes para proporcionar servicio doméstico ${ }^{84}$.

4. Consideraron lícito percibir honorarios por presidir las oraciones obligatorias y las supererogatorias, de acuerdo con la doctrina de Ibn 'Abd al-Hakam ${ }^{85}$.

El cadí 'Iyāḍ, en su Ikmāal ${ }^{86}$, recuerda que sólo Ibn 'Abd al-Hakam encontraba lícito cobrar un sueldo por presidir la oración. Todos los demás, entre los que nombra expresamente a Ibn Ḥabīb, consideraban nula la oración realizada detrás de un imām que cobrase un sueldo por ello. Sin embargo, en el Mi 'yär (VIII, 253-4) encontramos mencionados varios pleitos contra vecinos de diversas partes de al-Andalus que se negaban a pagar al imäm mientras que sus conciudadanos sí lo hacían.

\footnotetext{
${ }^{82}$ Véase Carmona González, A., «Aportación al estudio del contrato matrimonial en el Occidente islámico medieval», Miscellanea Arabica et Islamica, Lovaina, 1993, p. 58; Chalmeta Gendrón, P., «El matrimonio según el $K$. al-Watẩiq...», p. 48.

${ }^{83}$ Fatāwà, pp. 1486-7, núm. 545. Este texto de Ibn Habīb está también recogido en al$M i{ }^{*} y \bar{a} r$ de al-Wansarīsī, t. III, p. 106; cfr. ibidem, pp. 384-5.

${ }^{84}$ K. al-Wată’iq, p. 8.

${ }^{85}$ Creo que, a diferencia de algunas traducciones que encuentro, lo correcto es interpretar al-farida wa-l-náfila como esos dos tipos de plegaria pública, y no como «reparto de las herencias y del botín obtenido en la guerra santa».

${ }^{86}$ Apud al-Mi' yār al-mu' rib, ed. M. Ḥâŷŷ́1 et alii, Rabat-Beirut, 1981, t. VII, pp. 370-1.
} 
Así, por ejemplo, en una consulta efectuada a Ibn Rusd al-ŶYadd, los moradores de un hiṣn afirman que no encontraban imām que presidiera la oración del viernes en su mezquita si no era a cambio de salario. En su respuesta, el abuelo de Averroes no niega explícitamente el derecho del imām a reclamar un salario, pero afirma que ningún fiel está obligado a pagar la parte que le correspondiere si no se había obligado él personalmente a ello, y que si, por negarse a pagar, no había imām para el viernes, estaban obligados a ir donde se efectuara ese rito o a permanecer en un lugar de donde no hubiera obligación de desplazarse para asistir al rezo del viernes.

De ese mismo pasaje de la obra de al-Wanšarīsī se desprende que, si ese punto no generaba más conflictos, era porque frecuentemente el imām era

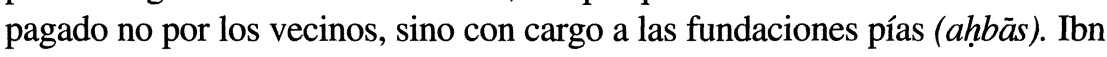
Mugīt dictaminó que, en el caso de que los fieles no quisiesen determinado imãm y éste recibiese su salario con cargo a bienes habices, había que demostrar fehacientemente su indignidad, pero que, si eran ellos quienes le pagaban directamente, no era necesario demostrar tal extremo.

\section{5. (Y también consideraron lícito percibir honorarios) por la en- señanza de la gramática y de la poesía. En ello seguían la opinión de Ibn Habïb.}

En la Mudawwana se expone el parecer de Mālik sobre la contratación de un profesor para la enseñanza de la poesía a un niño. Ibn al-Qāsim dice que

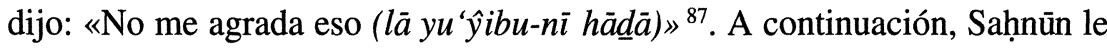
pregunta a su maestro por su opinión acerca de si era lícito contratar un escribiente ( $k a \bar{t} i b)$ que le escribiera a uno poesías y lamentos funerarios (nawh), e Ibn al-Qāsim responde que no oyó a Mālik decir nada al respecto, pero que a él personalmente no le parece aceptable aquello (lā yu' $\hat{y} i b u-n \bar{l})$, porque Mālik encontraba censurable que se vendieran libros de fiqh, cuanto menos de poesía.

Dice Ibn Mugī ${ }^{88}$ que «Mālik consideraba abominable (kariha) el estipular un precio por la enseñanza de la gramática, la poesía, el derecho y el reparto de las herencias, y que, sin embargo, Ibn Habīb consideraba lícito percibir honorarios por la enseñanza de la gramática, la salmodia de la lectura (tarsill), la poesía y las gestas de los árabes, siempre y cuando la poesía no contuviera cosas censurables».

${ }^{87} \mathrm{XI}$ (vol. VI), p. 62

${ }^{88}$ Muqni', p. 200. 
6. Permitieron la compra-venta de los libros de fiqh, ateniéndose a la doctrina de la mayoría de los seguidores de Mälik

En la Mudawwana ${ }^{89}$ Ibn al-Qāsim afirma que Mālik consideraba censurable la venta de libros de fiqh. Por tanto, se trata de una diferencia más con respecto a la doctrina de Mālik, de la que Ibn al-Qāsim es sólo el transmisor.

Ibn Mugīt se ocupa de esta cuestión en su Muqni` (p. 201) y cita a Ibn Saḥnūn, quien escribe que «no está permitido alquilar libros de fiqh, puesto que Mālik reprobaba su venta, ya que contienen las opiniones contradictorias (ijtiläf) de los ulemas». El argumento de Ibn Mugīt y otros es el siguiente: puede comprarse y venderse el Corán ${ }^{90}$, porque en él todo es verdad; pero no un libro de fiqh, porque lo allí contenido es posible que sea acertado y es posible también que sea erróneo, y -en todo caso- cuando aparecen opiniones enfrentadas, unas necesariamente contendrán errores, y permitiendo vender libros de fiqh se permitiría vender el error.

7. Daban por válidos los actos del incapaz (safih) que no hubiese sido puesto bajo tutela, siguiendo en eso lo dicho por Mälik en el Libro del Deudor. Ahora bien, las compras o ventas efectuadas después de la incapacitación eran nulas.

Es decir, para Mālik los actos del incapaz, por más que lo fuese de hecho y fuese manifiesta su incapacidad, serán válidos si la autoridad judicial no lo ha puesto bajo tutela (wilāya). Por el contrario, Ibn al-Qāsim sostenía que es la verdadera condición de cada cual la que hace que la venta que efectúe sea válida o nula ${ }^{91}$; así pues, en el caso de que, siendo capaz ( rašì d) estuviese sometido a tutela, esta verdadera condición (hâala) suya hará efectiva la venta que lleve a cabo, y viceversa. La mayor parte de los juristas mālikíes siguieron la opinión del Imām Mālik. En al-Andalus, tan sólo Ibn Lubāba (m. 314/926), que sepamos, mantuvo el mismo parecer que Ibn al-Qāsim, mientras que, según se afirma, la práctica jurídica ('amal) se atenía exclusivamente a las tesis del fundador del madhab.

${ }^{89}$ Tomo XI (volumen VI), p. 61.

90 La compraventa del Corán está autorizada en la Mudawwana, t. XI (vol. VI), p. 60. Aclara Ibn Wahb (ibidem) que, tratándose del Corán, en realidad «sólo es vendible la tinta, las hojas y el trabajo».

${ }^{91}$ Así lo dice el alfaquí Abū 'Abd Allāh al-Bāyĩ en sus Wațā'i $q$ (apud Mufid f. ${ }^{\circ} 21 a$ ). 
Ibn al-Hindī, en el siglo $\mathrm{X}$, menciona esta divergencia en el seno de la escuela mālikĩ y confirma que inicialmente la práctica de al-Andalus se atuvo a la doctrina que varios transmisores atribuyeron a Mälik ${ }^{92}$; pero que el califa al-Hakam II (m. 976) ordenó al cadí Muhammad b. Isḥāq Ibn alSalim que aplicara la doctrina de Ibn al-Qāsim, y que a partir de entonces los actos del incapaz realizados antes de que fuera declarado como tal fueron tenidos por nulos, pasando dicha norma (es decir, la de la retroactividad de la declaración de incapacidad) a ser la nueva práctica judicial. A modo de solemne promulgación, el propio cadí voceó la nueva norma un viernes a las puertas de la mezquita mayor ${ }^{93}$.

Un coetáneo de Ibn al-Hindī, Ibn al-'Ațtār, confirma en todos sus extremos la información anterior. En su $K$. al-Wațā' $i q$ (p. 337) señala que, aunque existiera un documento en que los testigos afirmaran que sabían que determinado individuo era safi $h$ un número determinado de años antes de la fecha del documento, los actos de tal individuo en ese espacio de tiempo eran válidos, de acuerdo con la doctrina de Mālik y sus discípulos, con excepción de Ibn al-Qāsim y de Muṭarrif. Sólo serían nulos, según dicho criterio mayoritario, a partir de la fecha del acta notarial o de la resolución judicial, asignándole tutor. Y añade: «En nuestro país se dictaminaba antiguamente ateniéndose a la opinión de Mālik, hasta que el califa al-Ḥakam al-Mustanșir bi-Llāh, al comienzo de su califato, ordenó a Muhammad b. al-Salīm, a la sazón qādị $l$ $\hat{y} a m \bar{a}^{\prime} a$ en Córdoba, que persuadiera a la gente para que se siguiese la opinión de Ibn al-Qāsim y Muțarrif en lo relativo a los actos del incapaz que no hubiera sido puesto judicialmente bajo tutela. Y así se dictaminó en esta cuestión hasta el final de su califato, abandonándose la opinión de Mālik.»

Ibn al-'Atțār relata también (p. 338) que le había sido referido a Mālik el caso de un príncipe cordobés, cuya tendencia a la dilapidación (safah) era tan grande que un día llegó a pulverizar una perla, cuyo valor era de mil dinares y se la bebió en una copa de vino, y que cuando se le preguntó (a Mālik) por la validez de los actos del pródigo (safih) que no hubiera sido puesto bajo tutela, repitió que eran válidos mientras aquél no hubiera sido incapacitado por resolución judicial, y, dirigiéndose a los andalusíes allí presentes, añadió: «Aunque fuera como ese príncipe vuestro.» E Ibn al-'Aț̣āar apostilla: «Se refería al de la perla.»

Tal como nos da a entender la cita del autor del $K$. al-Wațâ'iq, ese abandono de la doctrina de Mālik fue provisional y sólo duró hasta el final del

${ }_{92}$ La cita de Ibn al-Hindī aparece en los Aḥkām de al-Ša ‘bì, p. 337, núm. 689.

93 Ibidem, núm. 690. 
mandato de su promotor. Tenemos la confirmación en los Aḥäm de alSa'bī, quien, en la segunda mitad del siglo XI, afirma que, por lo que respecta a esa cuestión (que nos recuerda que había sido objeto de divergencias entre los alfaquíes de tiempos pasados), los jueces de su época consideraban válidos los actos de compra-venta del sometido a tutela siempre y cuando los hubiera realizado antes de su incapacitación legal ${ }^{94}$. En ese mismo texto de al-Ša 'bī el cadí Ibn Bassām afirma haber presenciado cómo el cadí Ibn Badr no aplicaba en este punto la doctrina de Ibn al-Qāsim ${ }^{95}$.

\section{Permitieron vestir ropas de seda en las campañas militares, si- guiendo la opinión de Ibn al-Mãŷisūn.}

La mayoría de la escuela mālikī encontraba reprochable vestir a los varones, especialmente a los niños, con seda (harīr), aunque admitían el uso de la seda cruda (jazz). Según Ibn Abī Zayd al-Qayrawānī ${ }^{96}$, Mālik dijo también: «No hay que vestir ropa de seda en las campañas militares, ni en ninguna otra ocasión.» Esa misma prohibición es recordada por Ibn Ŷuzayy, jurista granadino (693/1294-741/1340) ${ }^{97}$. Ahora bien, el alfaquí de Medina Ibn al-Māŷisūn (según afirma el mismo Ibn Ŷuzayy ${ }^{98}$ ) admitía la ropa de seda en el $\hat{y} i h \bar{a} d$ «para intimidar al enemigo». Sabida la influencia de Ibn alMâyisūn entre los primeros seguidores andalusíes de Mālik, es muy probable que fuese siguiendo su opinión como tal doctrina se introdujo en al-Andalus. Doctrina que no excluye la prohibición general de la ropa de seda entre los varones, y así sabemos que Ibn Habīio, el principal valedor de las ideas de Ibn al-Māŷisūn en al-Andalus, condenaba el empleo de la seda en la ropa masculina ${ }^{99}$.

${ }^{94}$ Aḥkàm, p. 118, núm. 107.

${ }_{95}$ Ibidem, núm. 108.

96 K. al- $\hat{Y} a \bar{m} m i$, ed. Abdel-Magid Turki, Beirut, 1990 (2. ${ }^{\text {a ed. }), ~ p . ~ 260, ~ n u ́ m . ~} 185$.

97 Véase Serrano Niza, D., «Los vestidos según la ley islámica: la seda», Boletín de la A. E. O., 39 (1993), pp. 158 y 163.

98 Ibidem, p. 164.

${ }^{99}$ Ibidem, p. 163. 
9. Y permitieron la mejora (de una parte alícuota) en el contrato de aparcería agrícola $(a l-m u z a ̈ r a ' a)$, si las partes no habían acordado que se sufragase el arrendamiento de la tierra con cereales u otro producto agrícola, ya que tal aparcería es un arrendamiento, no una sociedad, siguiendo la opinión de 'īsà b. Dīnār.

Ibn al-Qāsim consideraba la aparcería agrícola un contrato de sociedad en el que el precio o valor de la cesión de la tierra y el de la realización de las labores agrícolas debían ser considerados equivalentes, y los demás gastos (simiente, transporte...) corrían a partes iguales por cuenta de los contratantes; los beneficios se habían de repartir también a partes iguales, o en todo caso proporcionales a las respectivas aportaciones ${ }^{100}$. Como indica el texto, 'Îsà b. Dīnār (m. 212/827) permitía, con la condición expuesta, una excepción a esa doctrina general. También Sahnūn, en Ifrīqiya. Consta que en al-Andalus legitimaron también esta práctica los siguientes juristas, todos ellos del siglo Ix y primera mitad del x: Muhammad b. Yahyà b. 'Umar, Ibn Lubāba (m. 314/926), Aḥmad b. Jālid (siglo IX), 'Ubayd Allāh b. Yahyyà (m. 298/911) y Qāsim b. Muhạmmad (m. ca 277/890) ${ }^{101}$.

Ibn al-'Aț̣āa (m. 399/1009) expone en sus Wațā'iq (p. 61) que, según la doctrina de Mālik, el dueño de la tierra puede imponer al aparcero, como contrapartida, además de su trabajo, una serie de prestaciones, siempre y cuando todo ello fuera equivalente al valor del arrendamiento de la tierra, pero que, según la opinión de 'Tsà b. Dīnār, se permitía que la contrapartida del aparcero fuese de un valor menor que el del arrendamiento de la tierra, si se completaba el precio de dicho arrendamiento con una mayor participación en el reparto de la producción o con la percepción de otro tipo de productos.

La expresión li-anna-hā kirā' lā sarika, «porque es un arrendamiento, no una sociedad», aparece en el manuscrito de Abū Isḥāq, no en el del Mufid, y alude al debate que hubo sobre esta cuestión y sus implicaciones legales entre los discípulos de Mālik. Así, por ejemplo, Așbag consideraba la muzāra 'a un caso de arrendamiento, e Ibn al-'Atțāar (pp. 62-63), que se inclinaba por la opinión de Aṣbag, argumenta: «Ya que el dueño de la tierra le cede al labrador ('āmil) la mitad de la tierra para que la cultive para sí mismo, o la parte que hubieran pactado, a cambio de que él trabaje para el dueño la otra

${ }^{100}$ Véase la opinión de Ibn al-Qāsim expuesta en el Muqni ', p. 263. En esta misma obra de Ibn Mugīt (p. 264) se describen otras posibilidades de muzära' $a$. Por ejemplo, una que Mālik también consideraba válida: los dos contratantes ponen la tierra a medias, y uno pone la semilla y el otro la labor, siendo el reparto a partes iguales.

${ }^{101}$ Estos nombres, excepto el de Ibn Lubāba, constan en el Muqni ‘ de Ibn Mugīt (p. 264). 
mitad de su tierra o la parte restante. Es como si le arrendara la mitad de la tierra a cambio de su trabajo en la otra mitad, y ello es un arrendamiento que incluye una sociedad (wa-huwa kirā' wa-sarika fì nafsi l-kirā')» ${ }^{102}$.

10. Y no se consumía entre ellos el contrato de aparcería agrícola (muzãra'a), sino con el comienzo de las labores agrícolas, tal como sostiene Ibn Kināna ${ }^{103}$.

Esta norma daba la posibilidad, a cualquiera de los contratantes, de dejar la sociedad y recuperar su inversión, incluso después de establecido el contrato, si aún no había comenzado la cava o la siembra. En el caso de una aparcería prevista para varios años, esta doctrina permitía abandonar el compromiso antes de las labores de cada año, no una vez iniciadas.

Ibn Salmūn ${ }^{104}$ nos informa de que la entrada en vigor inmediata del contrato era defendida por Ibn al-Qāsim, mientras que el uso ('amal) de Córdoba no consideraba que la muzāra' $a$ estuviera vigente hasta que no se hubiera empezado el trabajo. El cadí Ibn Zarb sostenía explícitamente esta doctrina tradicional andalusí, en contra de Ibn Lubāba, que era de la misma opinión que Ibn al-Qāsim ${ }^{105}$. Pero, pese a este 'amal cordobés, Ibn Rušd (el abuelo de Averroes) defendía la posibilidad legal de acogerse a otras soluciones.

11. No permitieron dividir la casa en tanto no le quedara a cada uno de los copropietarios una parte de las habitaciones y del patio que fuera aprovechable y que le permitiera aislarse de los otros.

En la Bidāya ${ }^{106}$, dice Averroes que hay discrepancia entre Mãlik y sus discípulos respecto al caso de una copropiedad que, al dividirla, se llega a porciones que ya no tienen ningún aprovechamiento. Mālik opinaba que había que repartirla si uno de los derecho habientes así lo reclamaba, aunque

102 Cito según el texto de al-Sa‘bī (p. 333, núm. 677), donde este párrafo está más completo que en el K. al-Wațä'iq, ed. P. Chalmeta y F. Corriente.

103 J. Aguilera («Manuscrito, núm. 1.007...», p. 14) da de este párrafo la siguiente traducción, que me parece sorprendente: «Según jurisprudencia de Ibn Kināna, no extender formalmente los contratos, ni incluso en la fase de ejecución de los mismos.»

104 Kitāb al-'Iqd al-munaz̧zam, El Cairo, 1301-1884, II, p. 9.

105 Apud al-Sa'bī, Ahkām, p. 329, núm. 670.

106 T. II, p. 266. 
fuera hasta el punto de que resultaran de ahí porciones sin ninguna utilidad, donde no cupiera más que un pie. Según Averroes, ningún discípulo de Mālik, salvo Ibn Kināna, siguió esta opinión. Opinión que fue también la de los fundadores de otras escuelas, Abū Hanīfa y al-Šăfi 'ĩ. Por el contrario, Ibn alQāsim dictaminó que no se efectuara la división a no ser que le correspondiera a cada uno de los copropietarios algo que tuviera algún provecho y cuya utilidad no hubiera sido destruida por el hecho de la partición.

En eso la práctica judicial andalusí estaba de acuerdo con Ibn alQāsim. En lo que no le seguía era en que, en el caso de que las habitaciones de la casa fueran susceptibles de partición, y el patio no, Ibn al-Qāsim obligaba a compartir el patio - que habría de mantenerse, por lo tanto, indiviso-, mientras que los andalusíes no admitían el disfrute común del patio de la casa. Por consiguiente, si no era posible distribuir aquel espacio en partes que pudieran tener entrada independiente y aislamiento suficiente, era preciso vender la casa y repartir el precio. Tal divergencia con respecto a Ibn al-Qāsim consta en la obra de Ibn al-'Atțār ${ }^{107}$.

Esta norma implicaba la necesidad de aportar prueba pericial de que la casa era divisible sin perjuicio, antes de proceder a su división. Así se deduce de una consulta efectuada a Ibn Rušd el Abuelo ${ }^{108}$.

12. Consideraron ejercitable el derecho de retracto en bienes que no son susceptibles de partición, como el baño público y el molino. Esa era la opinión de Mālik.

La opinión de Mālik respecto al retracto del proindiviso ( $\left.̌ u f^{\prime} a\right)$, tal como está expuesta en el Muwațta' (II, p. 89), se basa en un hadì ț según el cual el Profeta concedió el derecho de retracto «sobre aquello que no había sido dividido entre los copropietarios (fí-mā lam yuqsam bayna l-surakâ'); pero si se hubieran establecido límites entre ellos, no habría opción a exigir el retrato (fa-id̄ā waqa' at al-hudūd bayna-hum fa-lā suf'a fi-hi)». Cabría suponer que entre lo que no ha sido objeto de partición se encuentran los bienes indivisibles; pero más adelante (II, p. 93), Mālik aclara: «Solamente se puede ejercer el derecho de retracto sobre aquello que admite válidamente ser dividido (inna-mā l-suf'a fi-mā yașluhu anna-hu yanqasimu).» Por tanto, esta doctrina de Mālik sería la contraria de la que se le atribuye en el texto

107 Ibn al- 'Aț̣āà, K. al-Wațā'iq, p. 190.

108 Fatāwà, p. 1359, núm. 481. 
que comentamos, salvo que entendamos la frase referida sólo al caso del baño o del molino, dos supuestos no contemplados en el Muwatta', sobre los que hubo discusión acerca de si eran bienes divisibles o no ${ }^{109}$.

Es en la Mudawwana donde consta que Mālik consideraba que era ejercitable la suf' $a$ en el caso del hammām (lo que quiere decir que él veía el baño público como un bien no dividido, pero divisible). Ibn al-Qāsim era de la opinión contraria (es decir: para él el hammām era una propiedad indivisible) ${ }^{110}$. Sin embargo, respecto a la postura de Ibn al-Qāsim, al-Sa 'bī dice lo siguiente: «Según Yahyyà, Ibn al-Qāsim era de la opinión de que no hay retracto en lo que no es divisible; pero en la Mudawwana él obliga al retracto en el caso del hammām, y eso que el baño es, según su parecer, de las cosas que no se dividen» ${ }^{11}$.

Según al-Jušanī, la práctica de los šuyūj de al-Andalus se atenía a la doctrina de Mālik ${ }^{112}$. Lo cual está corroborado por hechos como el siguiente: en Ceuta, que entonces dependía de al-Andalus, el alfaquí Yahyà b. Tammām quiso comprar la parte de alguien en la propiedad de un baño público y, para evitar que el copropietario pudiese ejercer su derecho de retracto, se simuló una donación (șadaqa), pues sólo así se podía obviar la reclamación del socio. Y, efectivamente, cuando éste denunció el trato, los alfaquíes de Ceuta respondieron negándole el derecho de retracto por tratarse de una șadaqa. No conforme con ello, el copropietario recurrió tal resolución ante los alfaquíes de la metrópolis (Córdoba) e Ibn al-Makwī (324/936-401/1011) dictaminó que la donación había sido una argucia y que el derecho de retracto era ejercitable en ese caso ${ }^{113}$.

Sin embargo, Ibn al-'Ațtār (330/942-399/1009) cuenta lo siguiente: en tiempos de 'Abd al-Raḥmān III, el cadí Muḥammad b. Isḥāq Ibn al-Salīm compró una participación en un determinado baño. Entonces, el otro condueño pidió ejercer su derecho de retracto y acudió al juez, Mundir b. Sa īid, $q \bar{a} d \bar{l} l$ l-ŷamā $a$ en Córdoba ${ }^{114}$, quien solicitó el asesoramiento de los alfaquíes. Aquellos juristas dictaminaron que, según la jurisprudencia de Ibn alQāsim, no era posible el retracto tratándose de un hammām. Ante ello, el

109 Véase Ibn Ruš, Bidāya, II, p. 258.

${ }^{110}$ Apud al-Wansarīsī, al-Mi'yār, 1981, t. VIII, p. 112

111 Ahkäm, p. 166, núm. 215.

112 Ibidem.

${ }^{113} M i{ }^{‘} y a \bar{r}$, t. VIII, p. 115; cfr. Cano Ávila, P., «Dictámenes jurídicos del sevillano Ibn alMakwī», Boletín de la A. E. O., 39 (1993), pp. 147-8.

114 Quizá sea interesante señalar que el comprador, Muḥammad b. Isḥāq, habría de ser precisamente el sucesor del cadí Mundir; véase al-JuSanī, Quḍàt Qurțuba, ed. I. al-Abyārī, El Cairo-Beirut, 1982, pp. 237-8. 
condueño que intentaba el retracto apeló al califa de Córdoba, haciéndole saber que se había sentenciado en su contra basándose en una doctrina distinta de la de Mālik. Inmediatamente, 'Abd al-Raḥmān escribió de su puño y letra al cadí Mundir b. Sa'īd indicándole que debía aplicar la doctrina de Mālik y fallar a favor del retrayente. El juez volvió a reunir a los alfaquíes y les pidió su dictamen diciéndoles: «¿Cuál es la doctrina de Mālik al respecto?» Le respondieron: «Mālik es de la opinión de que en este caso cabe el retracto.» Y el juez Mundir b. Sa 'īd falló otorgándole el derecho de retracto sobre la parte del baño que había sido vendida ${ }^{115}$.

En cuanto al molino, parece que hay unanimidad en tener por divisibles todos sus elementos (solar, edificaciones...) menos la piedra de moler ${ }^{116}$. La postura de Ibn al-Qāsim al respecto está confirmada por un texto de Ibn Abì Zamanīn ${ }^{117}$ en que este autor afirma que Ibn al-Qāsim opinaba que era ejercitable el retracto en el edificio del molino y en todas sus utilidades, pero no en la piedra con la que se muele, si se vendiera sola. Ibn Abi Zamanīn opina que éste es también el caso del molino que no está asentado sobre un solar, sino colocado en medio de la corriente fluvial, es decir, que no es ejercitable en él el derecho de retracto ${ }^{118}$.

En época califal, al jurista Ibn al-Makwī, que ya hemos mencionado, le consultaron acerca de un hombre que compró una parte (nașìb) en un molino hidráulico, en cuyo casal había una sola muela, lo cual hacía que, si se procedía a su partición, ya no sería posible la molienda. A raíz de eso, los copropietarios exigieron ejercer el derecho de retracto sobre la parte que había sido vendida. El jurista respondió que, según su criterio, tenían opción a exigir el retracto, pero que en tal cuestión no había unanimidad entre los alfaquíes ${ }^{119}$.

13. También lo consideraron ejercitable en el caso de bienes sujetos a cargas u obligaciones, de acuerdo con la doctrina de Ašhab.

Según Ibn al-Hindī (320/932-399/1008), el hecho de que determinado patrimonio esté gravado con alguna carga (lo más frecuente es que estuviera afecto al pago de pensiones) no anula el derecho de retracto, y, según él, a

\footnotetext{
115 Apud al-Ša'bī, Ahkām, p. 71, núm. 7.

116 Ibn al-'Atțār, Watā̄'iq, p. 191.

117 Apud al-S̆'bī, Aḥām, p. 73, núm. 12.

118 Ibidem., núm. 13.

119 Apud al-Sa'bī, Ahkām, p. 86, núm. 41.
} 
ese criterio se atenía la práctica judicial de su época ${ }^{120}$. Sin embargo, según nos da a conocer al-Ša ‘bī en sus $A h k a ̄ m$ (p. 85, núm. 38), eran varios los que opinaban lo contrario, pues asimilaban el retracto a una venta, y la misma regla que impedía adquirir unos bienes gravados con una pensión impedía acceder a ellos ejerciendo el derecho de retracto. Entre quienes así pensaban estaba el cadí Muhammad b. Yabqà b. Zarb (m. 381/991), quien aducía a su favor la autoridad de Ibn al-Qāsim. El mismo Ibn Zarb nos explica que la razón por la que Ašhab consideró ejercitable la suf' $a$ en ese caso era que consideraba lícita la venta de bienes afectos al pago de una pensión.

14. No aceptaban garante de una deuda si éste no se había comprometido ante dos testigos. Era doctrina de Sạ̣nūn.

No he encontrado alusión a este punto en la jurisprudencia andalusí que he examinado. En la Mudawwana se admite el contrato oral y sin especiales requisitos ${ }^{121}$.

15. Y obligaban (al deudor) cuyo patrimonio no fuera conocido, a aportar un fiador que garantizara que presentaría prueba testimonial suficiente acerca de sus bienes. Si no disponía de tal fiador y si sus testigos no residían en aquel lugar, era encarcelado. En esto seguían la opinión de Ašhab ${ }^{122}$.

Se trata de una aplicación de la hamālat al-nafs o damān al-waŷh («caución de comparecencia»), uno de los dos tipos de fianza (el otro es la hamälat al-mäl o al-haqq, es decir, el aval que responde de la solvencia económica del deudor, mencionado en el párrafo anterior del documento). Es, sin duda, la fianza que Averroes menciona de pasada en su Bidāya (II, p. 298), dándole el nombre de kafälat al-maŷhül, admitida por Mālik y rechazada por al-Šăfi'î. La obligación del hamìl al-waŷh es asegurar que el deudor estará presente cuando venza el plazo que se le dio para pagar. Si el deudor es forastero y tiene que ir a buscar a quienes certifiquen acerca de él,

${ }^{120}$ Apud al-Ša 'bī, Ahkām, p. 251, núm. 447; cfr. ibidem, p. 71, núm. 8.

${ }^{121}$ Así lo dice López Ortiz en «Recepción...», p. 165, nota 860.

${ }_{122}$ Mi traducción de este párrafo difiere bastante de la que López Ortiz publicó en su «Recepción...», pp. 165-6. 
necesitará un fiador que responda de que volverá; si no, habrá de ser encarcelado para asegurarse de que no escapará.

La opinión de Ašhab que aquí se menciona sigue la doctrina de Mālik, transmitida por Ibn al-Qāsim en la Mudawwana ${ }^{123}$, según la cual no debe encarcelarse al deudor que no satisface su deuda, excepto en dos casos: 1) que se tema que esté escondiendo dinero, y entonces habrá de permanecer en prisión hasta que lo entregue, y 2) que se ignore su verdadera situación patrimonial, y en ese caso también está prevista la cárcel, mientras se investiga sobre él; en este último supuesto se le permite librarse del encarcelamiento poniendo un fiador (hamil). Pero consta en la misma Mudawwana ${ }^{124}$ la siguiente opinión personal de Ibn al-Qāsim: el demandante no puede exigir que su demandado aporte un fiador mientras busca la prueba a su favor, lo cual es aplicable al caso contemplado en este punto del documento.

No he encontrado mención a este ijtiläf en la jurisprudencia andalusí que he podido consultar.

16. Entre las cuestiones (en que se separaban de Ibn al-Qāsim) estaba la de que la cosa reivindicada entraba en la responsabilidad ${ }^{125}$ de aquél de quien era reivindicada y (por tanto) sus frutos o beneficios le pertenecían $^{126}$.

Efectivamente, Ibn al-Qāsim no era de este criterio, pues en la Mudawwana $^{127}$ afirma que los productos de la cosa reivindicada van a quien obtiene la reivindicación.

En cuanto a la práctica andalusí, existe el siguiente testimonio de Ibn al- 'Atțār (p. 509): tratándose de una tierra y habiéndose resuelto la reivindicación a favor del demandante, si dicha tierra estuviera sembrada y fuera la época de la cosecha, ésta habría de ser para el que la cultivó. Si en la sentencia el demandado fuera calificado de usurpador ( $g a \overline{a s i b}$ ), debería pagar el precio del arriendo de la tierra, pero no entregar sus frutos. Ahora bien, si en

${ }^{123}$ Tomo XIII (vol. VII), pp. 54-5.

${ }_{124}$ Tomo XIII (vol. VII), pp. 122-3.

${ }^{125}$ Dice Averroes en su Bidāya (II, p. 326): «Entiendo por responsabilidad (damān) el hecho de que si la cosa se perdiera estando en su poder, se perdería a su costa (A 'ni bi-l-damān anna-hà takūnu min jasārati-hi id̄ā halakat 'inda-hu).»

${ }_{126}$ López Ortiz («Recepción», p. 166) entiende esta frase de la siguiente manera: «En materia de fianzas aceptan también que si la cosa debida a su acreedor es afianzada por persona que es, a su vez, acreedora de éste, puede haber lugar a compensación» (sic).

127 Tomo XIV (vol. VII), p. 85. 
la sentencia fuera considerado poseedor de buena fe, ni siquiera tendría que satisfacer ese alquiler. Pero, en el caso de que dicha tierra estuviera plantada de árboles, los frutos serían para el demandante una vez que le hubiera sido reconocida la propiedad de los árboles, pues se consideraba que esos frutos eran parte del bien reivindicado; no obstante, si el demandado había invertido allí dinero o trabajo, tendría derecho a que se le reembolsase.

17. Y consideraban obligatorio el secuestro preventivo de la cosa reivindicada, de modo que apartara de su disfrute a su poseedor, siempre y cuando los derechos del demandante fueran (inicialmente) confirmados por dos testigos. Lo dijo Mälik en el Muwața' y lo dijo otro en la Mudawwana.

La doctrina de Mālik, tal como aparece en el Kitāb al-Šahādāt de la $M u$ dawwana ${ }^{128}$, es que para obtener la retención judicial de la cosa reivindicada no basta con la simple demanda, sino que hay que fundamentar la reclamación con los dos testigos preceptivos, necesarios. La razón de que el bien no le sea entregado inmediatamente al reclamante es el hecho de que, a partir de ese momento, el demandado tiene un plazo para presentar contraprueba o prueba a su favor; de ahí la necesidad del secuestro preventivo para que la propiedad en cuestión no sufra menoscabo.

Sobre la opinión de Ibn al-Qāsim al respecto, encuentro lo siguiente en el Muntajab de Ibn Abī Zamanīn ${ }^{129}$ : en la 'Utbiyya refiere 'Isà que Ibn al-Qāsim fue preguntado acerca de alguien que reclamaba la propiedad de unos olivos presentando inicialmente sólo un testigo y pidiendo que se le dejara designar un apoderado (wakil) que vigilara el fruto en el momento de su recolección y de su prensado. En su respuesta, Ibn al-Qāsim opinaba que, si el testigo era ' $a d l$, el juez podía tomar juramento al demandante y entregarle el fruto, y si dicho magistrado fuera de los que no sentenciaban en base al testimonio único corroborado por juramento, entonces debería permitir la designación de apoderado y la retención judicial.

${ }^{128}$ Apud Ibn al-'Aț̣āar, Watăà'iq, p. 513.

${ }^{129}$ Tesis de M. Arcas, pp. 454-5. 
18. Quien negaba adeudar algo y luego lo reconocía y aportaba la prueba de que había satisfecho su obligación, dicha prueba no le servía. Así opinaban Ibn Dīnār, Muțarrif e Ibn al-Māŷišūn. Es el caso de aquél a quien le reclaman una indemnización, un depósito o una deuda y niega tener tal obligación, y posteriormente lo reconoce y aporta prueba de haber entregado lo que debía; tal prueba no le sirve por cuanto la había desmentido previamente con su negativa a aceptar los hechos.

En el Muntajab al-Ahkām, Ibn Abī Zamanīn ${ }^{130}$ incluye una cita del libro de Ibn Habīb que nos muestra a este alfaquí como introductor en al-Andalus de dicha doctrina, oída a Muțarrif e Ibn al-Māŷisūn.

Ibn al- 'Aț̣ār, en sus Wațā'iq (pp. 505-6), explica que se trata del caso de quien empieza negando el hecho mismo del trato o negocio, pero luego, cuando le prueban que tal trato existió, aporta un documento liberatorio de deuda. $E$ indica que ante ello había dos doctrinas: la de quienes opinaban que el juez debía negar validez a su prueba, pues sus testigos demostraban que él había mentido al negar la raíz de aquel litigio (el documento que comentamos dice lo contrario: que él había desmentido previamente la prueba), doctrina aplicada en al-Andalus, y la de quienes reconocían validez a su prueba testifical a condición de que declarase que aquello se le había borrado de la memoria y prestase juramento sobre cuanto recordase al respecto. Esta segunda opinión Ibn al-'Aț̣āar se la atribuye a Mālik (ruwiya 'an Mālik) y no a Ibn al-Qāsim.

19. A la hora de determinar, en su ausencia, la situación, en cuanto a pobreza o riqueza, de quien se hubiere ausentado de su mujer, dicha situación será la del momento de su partida ${ }^{131}$. Así lo dijo Ibn Näfí'.

No he encontrado jurisprudencia respecto a este punto.

130 Tesis de M. Arcas, núm. 46.

131 No sé qué quiere decir J. Aguilera («Manuscrito, núm. 1.077...», p. 15) cuando traduce: «El considerar a quien se ausenta de junto a su esposa, durante el período de ausencia, como al sujeto a impedimento.» 
20. Yobligaban a corroborar con juramento colectivo el testimonio de un grupo de personas no habilitadas como testigos.

Respondiendo a una pregunta sobre qué sentencia debía recaer sobre alguien acusado por el testimonio de varias personas no adules, Ibn Rusd al-Ŷadd ${ }^{132}$ dice que si tales personas eran conocidas como recusables ( $\breve{u} u \bar{u} d$ gayr 'adūl tu'raf ŷrhatu-hum) no se podía condenar a nadie en base a tal testimonio. Ahora bien, si tales personas no habían recibido la habilitación como testigos, pero tampoco se supiese si eran indignos o aceptables, había dos opiniones, ambas atribuidas a Mālik, según Ibn Rušd: 1) que se admitiese su testimonio, precedido o seguido de juramento colectivo (qasāma), y 2) que se rechazase tal testimonio porque en ese caso no era legal la qasāma.

21. No daban validez al testimonio acerca de la firma de un testigo, con la única excepción de los casos de habices inalienables establecidos en favor de la posteridad, siempre que ese testimonio fuera acompañado de la pública notoriedad ${ }^{133}$ [de que ese habiz fue instituido en la forma en que se testifica].

Aquí no parece que la particularidad lo sea sólo respecto de Ibn alQāsim, sino también respecto de Mālik y muchos otros. En efecto, tal como el cordobés Ibn Zarb (m. 381/991) afirma ${ }^{134}$, «es válido el testimonio acerca de la firma, de acuerdo con la doctrina de Mālik, en toda clase de asuntos»; pero, a continuación, añade: «Mas la práctica que estuvo vigente entre nosotros fue darle validez sólo cuando se trataba de habices establecidos en favor de la posteridad de alguien». El uso del verbo en pasado en la cita del cadí Ibn Zarb (ŷarà bi-hi l-'amal 'inda-nã) ¿indica que habla de una norma que ya no estaba vigente en la época de este cadí? En todo caso, está atestiguado que en tiempos de los primeros emires omeyas de alAndalus había quienes no admitían tal testimonio. Se sabe que el cadí cordobés Muḥmammad b. Bas̄īr se negó a admitir una atestación sobre la letra o firma, lo que impidió que se le reconociera cierto derecho a un tío del emir al-Hakam I.

${ }^{132}$ Fatāwà, p. 1365, núm. 484.

${ }_{133}$ Difiero de la traducción de J. López Ortiz, que pone en forma negativa este segundo enunciado: «Pero no cuando concurran por esta razón testimonios de mera fama pública.»

${ }^{134}$ Apud Mufid, f. ${ }^{\circ} 19 \mathrm{~b}$. 
Sa'īd b. 'Abd Rabbi-hi (m. 356/967) e Ismā'īl b. Muhammad (m. 357/968) opinaron que el testimonio acerca de la firma es débil. Por su parte, al-Jušānī (m. 371/981), que vivió en la misma época que Ibn Zarb, afirma que, aunque la licitud del testimonio sobre la letra de un testigo había sido algo muy debatido entre los seguidores de Mālik, la costumbre que habían heredado los jueces de Córdoba de sus predecesores era la de admitir su validez (qad ŷarà l-'amal mina l-qud̄āt bi-baladi-nā Qurțuba bi-iŷāzat al-sahāda 'alà jațt al-sāhid). Y añade lo siguiente: «Hemos comprobado que ese ha sido el proceder de los jueces antiguamente y en nuestros días. Y nunca he oído, ni ningún jurista me ha dicho que distinguieran entre el testimonio acerca de la escritura en asuntos de bienes habices y el testimonio acerca de otros asuntos, en ninguna circunstancia. Y presencié cómo Muḥammad b. Abī 'Isà, juez mayor de Córdoba, sentenció en base a la validez del testimonio sobre las firmas de unos testigos entonces difuntos, en un asunto de dotes matrimoniales de las mujeres» ${ }^{135}$.

Pese a las afirmaciones de al-Jušanī, el alfaquí granadino Ibn Abī Zamanīn (m. 399/1008) atestigua: «La práctica judicial de nuestros días rechaza el testimonio acerca de la firma, salvo, exclusivamente, en asuntos de bienes habices (...). Además, tal testimonio no constituye prueba plena mientras no presten testimonio testigos que afirmen que nunca han dejado de oír que aquello acerca de lo cual atestiguan es un habiz, del que se tomó posesión cumpliendo los requisitos legales» ${ }^{136}$. Otro jurista de la misma época, el notario cordobés Ibn al-Hindī (m. 399/1008), «el alfaquí más aventajado de su tiempo», señala respecto a esta cuestión que «quien admite dicho testimonio en los habices antiguos se ve obligado a admitirlo en los demás casos, pues los derechos son todos iguales ante Dios» ${ }^{137}$.

Al-Sa ‘bī (s. XI), al abordar esta cuestión, cita a Muțarrif, quien transmite la doctrina de Mālik según la cual era lícito el testimonio acerca de la fir-

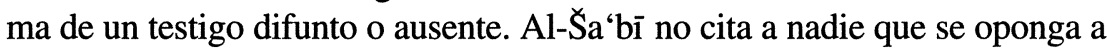
esta doctrina, y tan sólo recuerda que hay discrepancia en cuanto a determinar a qué distancia habría de encontrarse el testigo para ser considerado ausente $^{138}$.

${ }^{135}$ Mufid, f. ${ }^{\circ} 19 \mathrm{~b}$.

136 Muntajab al-ahkām, I, p. 529, núm. 26.

137 Encuentro esta cita en la nota 2 a la página 1347 de la ed. citada de las Fatāwà de Ibn Rusd.

${ }^{138}$ Aḥkäm, p. 181, núm. 255. 
22. Y omitían en los contratos la ifirma? (tahliya) ${ }^{139}$ y la descripción de la persona contra la cual era invocable el testimonio ${ }^{140}$.

No he encontrado jurisprudencia respecto a esta cuestión; tan sólo he hallado la norma de que era imprescindible la identificación del demandado ( 'ayn al-mațlüb) por parte de los testigos ${ }^{141}$.

23. No autorizaban al tutor a tutelar también a los hijos del incapacitado puesto bajo su tutela, excepto si disponía para ello de autorización judicial expresa.

Le preguntaron a Ibn 'Attāb (m. 462/1069) por este caso, es decir, el de un tutor en cuyo documento de designación no se mencionaba a los hijos menores del tutelado, y respondió que lo que se desprendía de la doctrina mālikī era que debía velar por ellos e intervenir sus compras y ventas. Y termina diciendo: «Pero la costumbre entre los jueces fue (ŷarà bi-hi l- 'amal 'inda l-qudāt) la de considerar que no le estaba permitido tutelarlos» ${ }^{142}$.

24. Se obligaba en al-Andalus al que prestaba juramento, en el caso de que estuviera obligado a jurar, a hacerlo puesto de pie en la dirección de la alquibla. Así lo dice Ibn al-Māŷǐ̌ūn, y es la norma que se sigue.

Esa obligatoriedad de jurar puesto de pie cara a la alquibla no consta que fuera nunca mencionada expresamente por Mālik, quien tan sólo afirmó que debía jurarse en la mezquita aljama en los lugares más solemnes

139 La equivalencia más admisible, en el contexto de la frase, que dan los diccionarios para esta palabra es «descripción», concepto que ya está expresado más adelante con la palabra șifa; sin embargo, encuentro el término tahliya en otros textos con el significado de «inscripción - con finalidad ornamental - de una frase en un objeto", lo que me hace preguntarme si alguna vez no ha significado «firma» palabra que cuadra perfectamente en este contexto, pues, además de los dos testigos, la firma del que adquiere una obligación puede ser muy útil a la hora de una reclamación.

140 No puedo más que considerar disparatada la siguiente traducción que López Ortiz («Recepción», p. 167) hace de esta frase: «Toleran el matrimonio en el que el que da por esposa a la mujer se reserva una parte de la dote (el padre o el hermano), siempre que se haga constar por escrito esta estipulación y se observen todas las cláusulas restantes.»

141 Ibn Rusd, Fatāwà, p. 1586, núm. 596.

142 Apud al-Sa'bī, Aḥkām, p. 180, núm. 253. 
( $a^{\prime}$ zam). Y cuando Saḥnūn le pregunta a Ibn al-Qāsim por la doctrina de Mālik respecto a si se debía jurar de cara a la alquibla, responde que nunca oyó a Mālik decir eso y que él personalmente no opinaba que aquello fuera una obligación ${ }^{143}$. Pero fue el mediní Ibn al-Māŷišun quien inculcó en sus discípulos españoles la obligatoriedad de tal práctica, que consta como la única vigente en al-Andalus.

\section{A MODO DE CONCLUSIÓN}

El corpus de doctrina jurídica mālikì es, pese a lo que a veces se cree, plural y hasta podríamos decir flexible. Por un lado, algunas opiniones de Mālik no son aceptadas por determinados ulemas que se llaman seguidores suyos y, por otro, las divergencias entre los diferentes doctores del madhab son frecuentes. Sin embargo, ante tal situación de falta de unanimidad doctrinal, jueces y muftíes de al-Andalus, en lugar de tener libertad para aplicar la opinión que mejor les pareciera, se veían de hecho obligados a seguir, de entre esos criterios enfrentados, aquél que se solía aplicar en el lugar en que ejercían su función ${ }^{144}$. Ello es bastante coherente y esperable, pues la situación contraria engendraría desorden jurídico, ya que los ciudadanos no sabrían a qué leyes concretas estaban de facto obligados. Por esa razón, cuando se decidía empezar a aplicar otra norma, se anunciaba públicamente; como sucedió cuando al-Ḥakam II dispuso que la incapacitación tuviera efectos retroactivos. No obstante, la posibilidad de aplicar una norma inusual en la región, pero defendida por alguna autoridad doctrina mālikī, no se veía como algo totalmente rechazable, tal como se desprende del hecho de que para anular una sentencia en base a su ilegalidad era necesario mostrar que el juez no había aplicado una norma sobre la cual no había divergencia entre los ulemas ${ }^{145}$.

La lista que hemos editado, traducido y comentado no recoge todas las divergencias ni con respecto a Mālik ni con respecto a Ibn al-Qāsim. Pese a lo cual, el ms. 1077 dice claramente en su título (y el Mufid lo da a entender) que esas eran las cuatro y las dieciocho cuestiones en que los andalusíes se apartaron de Mālik y de Ibn al-Qāsim respectivamente. Ignoro por qué tal re-

\footnotetext{
143 Mudawwana, XIII, p. 49.

144 Una buena muestra de ello son los numerosos casos recogidos por P. Chalmeta en su trabajo sobre el 'amal andalusí (véase nota 1).

145 Véase Ibn al-'Aț̣ār, Wațā'iq, pp. 638 y ss.
} 
lación parcial pretende pasar por exhaustiva. Como también desconozco cuál fue la razón por la que alguien se decidió a establecer ese catálogo de usos jurídicos. Muy probablemente tenga que ver con la época en que fue redactado. Pero sobre la fecha de composición tampoco nos podemos pronunciar con total seguridad. Al haber aparecido en una obra de Abū Ishạā alGarnāțī, no puede ser posterior a la época almorávide, aunque no me parece que haya que descartar totalmente que sea anterior ${ }^{146}$.

De los materiales que he podido acumular para realizar este trabajo, se desprende que las divergencias con respecto a los criterios de Mālik no pervivieron más allá de la época almorávide, aunque no parece que sea porque bajo ese régimen se decidiera restablecer la pureza mãlikī, sino porque desde tiempos atrás eran cada vez más numerosos los ulemas que decidían seguir la opinión del fundador del madhab. Por el contrario, muchas de las discrepancias con respecto a Ibn al-Qāsim las encontramos todavía en el siglo XIII, y tengo la impresión de que se mantuvieron hasta el final del reino nazarí de Granada. Pero sobre esa cuestión no puedo ser tajante hasta haber examinado un número de textos mayor del que he manejado en esta ocasión.

\section{RESUMEN}

El ms. árabe núm. 1.077 de El Escorial contiene una obra de Abū Ishāa al-Garnāṭi (ob. 1183), cuyo último capítulo lo constituye la enumeración de veintidós normas jurídicas, en cuatro de las cuales los andalusíes no siguieron la doctrina de Mālik, y en las dieciocho restantes se apartaron de la de Ibn al-Qāsim. Ese mismo texto aparece también al final de $K$. al-Mufíd del cordobés Ibn Hisām (ob. 1209). En este artículo su autor, tras definir el concepto de 'amal local (usus fori), plantea la cuestión de la autoría del citado texto, ofrece una edición crítica y traducción del mismo a partir de las dos fuentes mencionadas y hace un estudio diacrónico de la aplicación en al-Andalus de esas controvertidas normas. Dicho estudio muestra que tales diferencias con respecto a Mālik o Ibn al-Qāsim no siempre se mantuvieron, sino que caracterizaron más bien el fiqh «temprano» andalusí.

\section{ABSTRACT}

In the Arabic manuscript n. ${ }^{\circ} 1077$ from El Escorial we find an Abū Ishạā al-Gharnātị's (ob. 1183) work whose last chapter consists of the enumeration of

${ }^{146} \mathrm{Si}$ lo suponemos de tiempos almorávides, podemos quizá ver en él una especie de «circular» para ayudar a los cadíes no andalusíes, tal como me sugiere M. I. Fierro, quien ha tenido la gran amabilidad de leer el original de este trabajo y hacerme algunas muy útiles observaciones y correcciones, que le agradezco públicamente. 
twenty-two juridical rules: in four of them the andalusiyyūn did not follow Mālik's doctrine, and in the other eighteen they disagreed with Ibn al-Qāsim. The same text appears also at the end of Ibn Hishām al-Qurțubī's (ob. 1209) K. al-Mufid. In the present article, its author, after explaining the notion of local 'amal (usus fori), raises the problem of this text's authorship, presents a critical edition and translation of it from the two aforementioned sources and makes a diacronic research into the application in al-Andalus of those controversial norms. The research shows that those divergences with regard to Mālik's or Ibn al-Qāsim's opinions not always remained in force but rather characterized the «early» Andalusian jurisprudence. 